In press at Cognition.

\title{
Corporate insecthood
}

\author{
Nina Strohminger* \\ Department of Legal Studies and Business Ethics \\ The Wharton School \\ University of Pennsylvania \\ Matthew R. Jordan \\ Department of Psychology \\ Yale University
}

\begin{abstract}
Whether the corporation should be considered a person is a matter of active academic and public debate. Here, we examine whether, and in what ways, ordinary citizens conceptualize the corporation as a person. We present evidence that corporations are anthropomorphized, but only to a certain degree. Compared with other entities, the average corporation is considered about as similar to a person as an ant. Corporations differ in the extent to which people are willing to grant them personhood however, and this pattern is predicted by how salient the organization's mental and moral traits are. This process of anthropomorphization has important downstream consequences, increasing support for granting legal rights and responsibilities to corporations. Because our studies show that this relationship also obtains for animals, we conclude that perceptions of corporate personhood draw on a more general set of rules for assessing an entity's personhood.
\end{abstract}

Keywords: corporate personhood | anthropomorphism | legal persons | animal rights

In two recent landmark cases, the U.S. Supreme Court has ruled that corporations should be granted certain rights shared by natural persons (Citizens United v. Federal Election Commission, 2008; Burwell v. Hobby Lobby Stores, Inc., 2014). These rulings are not without precedent: recognition of corporate personhood stretches back centuries, and is

\footnotetext{
* To whom correspondence should be addressed: humean@wharton.upenn.edu. The authors would like to thank Geoffrey Goodwin, Paul Rozin, Corey Cusimano, Gwendolyn Gordon, David Melnikoff; Elijah Fullerton, who performed coding for textual analysis; the many people who provided positive affirmation about the paper's title; and Dorsa Amir, who made extremely minor but aesthetically pleasing tweaks to Figure 1 . All data and study materials are available on the OSF repository at: https://osf . io/e2g7v/.
} 
woven into the jurisprudence of many industrialized nations (Trustees of Dartmouth College v. Woodward, 1819; Santa Clara County v. Southern Pacific Railroad, 1886; Dewey, 1925; Ruskola, 2013; Gordon, 2015). Juridical personhood originated as a way of recognizing the corporation as an entity separate from the individuals that constitute it, thus making possible various legal functions, such as the right to own property and enter contracts (Kantorowicz, 1957). However, over time this conceptualization has expanded to consider other rights, such as free speech. Perhaps when a court recognizes corporate personhood, or when a politician declares, “Corporations are people, my friend!” (as Mitt Romney did, following the Citizens United ruling) this represents nothing more than a figure of speech. But it's also possible that corporate personhood belies an underlying anthropomorphization. That is, there may be a connection between anthropomorphic personhood (similarity to humans) and support for legal personhood (the extension of rights and responsibilities to nonhumans; Salmond, 1902). We know surprisingly little about how these concepts play out in the minds of ordinary citizens (Mentovich, Huq, \& Cerf, 2016).

People readily find humanity in the unlikeliest of places, from frogs to gods to gusts of wind (Heider \& Simmel, 1944; Barrett \& Keil, 1996; Boyer, 2001; Bering, 2002; H. M. Gray, Gray, \& Wegner, 2007), a phenomenon known as anthropomorphization. Whether an entity will be anthropomorphized is determined, in part, by whether it displays humanlike characteristics, including sentience and the capacity for intentional action (Epley, Waytz, \& Cacioppo, 2007; Waytz, Cacioppo, \& Epley, 2010). Corporations have some of these features, making them a potential target for anthropomorphic thinking.

Sure enough, extant empirical work indicates that corporations are afforded at least some of the features of persons. People spontaneously attribute mental states to corporations, particularly agency (Knobe \& Prinz, 2008; K. Gray \& Wegner, 2010; Huebner, Bruno, \& Sarkissian, 2010; Phelan, Arico, \& Nichols, 2013; Malle, 2010; Sytsma \& Machery, 2009; Rai \& Diermeier, 2015). Corporations are granted personality traits, much as humans are (Aaker, 1997; Aaker, Vohs, \& Mogilner, 2010). Corporations are held morally responsible for their actions, sometimes even more so than individuals (Jago \& Laurin, 2017; Jago \& Pfeffer, 2019; Michael \& Szigeti, 2019; though see Haran, 2013). Reasoning about corporate and human behavior engages overlapping neural substrates, especially in brain areas implicated in theory of mind (Jenkins, Dodell-Feder, Saxe, \& Knobe, 2014; Plitt, Savjani, \& Eagleman, 2015). At the same time, the personhood of corporations seems bounded in certain ways. People grant consciousness and other experiential states to corporations only reluctantly (Knobe \& Prinz, 2008; Rai \& Diermeier, 2015) and in general attribute fewer mental states to them (Critcher \& Dunning, 2014; Cooley et al., 2017; Jago, Kreps, \& Laurin, in press). There is also a tendency to see profit-driven corporations as bad moral actors (Plitt et al., 2015; Bhattacharjee, Dana, \& Baron, 2017; Jago \& Pfeffer, 2019), which may further degrade their incipient humanity.

Though these studies are suggestive, none of them have examined folk judgments of corporate personhood directly. We are given little sense of how these whiffs of personhood stack up against other entities: How does Google's personhood compare with a fetus, a robot, a tree? Nor do we have much sense of whether there is variance in perceived personhood across corporations (is Google more of a person than Pfizer?), and what might determine this variance. Perhaps most significantly, we know nothing of whether anthropomorphic personhood impacts willingness to grant rights and responsibilities to 
corporations-that is, legal personhood. (Following jurisprudential convention, we will use the term "legal personhood" to refer to the condition of having the rights and responsibilities of natural persons.)

The puzzle of corporate personhood is deepened by the fact that the corporation is comprised of individuals who are themselves persons. ${ }^{1}$ In a world where the corporation is understood as nothing but the human collective that gives rise to it, we would expect assessments of corporate personhood to be unabashedly high. Then again, ordinary people may understand the corporation as a separate entity-and this entity could be anthropomorphized to varying degrees, depending on its emergent properties. A folk concept of the corporation that is high in entitativity would be in line with the legal understanding, where corporate personhood is premised on the idea that the corporation is a distinct entity from its members. Indeed, it was the desire to define an incorporated body that is legally dissociable from those within it that such laws emerged in the first place (Kantorowicz, 1957). A subsidiary goal of this paper is determine whether the person-composition of corporations is the driving force behind judgments of corporate personhood.

\section{Study 1}

Our initial study was aimed at assessing the extent to which various corporations are anthropomorphized, compared with a range of other entities. By sampling a variety of corporations, we can get a sense of the range of corporate personhood-does it spread the width of the scale, or does it wedge itself more narrowly? By comparing corporate with non-corporate entities, we can gain a more concrete understanding of what these ratings mean. A related goal for this study is to measure which factors predict how anthropomorphized a corporation will be. Previous work gives indirect evidence that mental and behavioral features may be important. However, personhood judgments have never been measured directly, nor is the relative contribution of these factors known. Because we are measuring the features of corporate and non-corporate entities, we can also see if the factors that predict personhood for corporations are the same as the ones that predict personhood more generally. To the extent that these factors are the same, this would suggest a common cognitive process underlying the determinants of personhood.

\section{Methods}

All studies reported in this paper were approved by the Institutional Review Board of the University of Pennsylvania, and all participants gave informed consent. All data and study materials are available on the OSF repository at: https://osf . io/e2g7v/.

Materials. We generated a list of 76 entities (Fig. 1; see Table S1 of Online Supplemental Material for full list). Approximately half of these (43) were organizations. Our focal point was for-profit corporations, mostly publicly traded (25), some privately or governmentally held (5). Non-profit, mostly charitable, organizations were included (13) as a comparison class, as they share structural features with corporations (e.g. collective) but differ in their purpose-prosociality rather than revenue. We included two metonyms (Hollywood, Wall Street) and agentic abstract concepts (the invisible hand of the market,

\footnotetext{
${ }^{1}$ This may have been what Romney meant in his oft-quoted proclamation, but "Corporations are made up of people, my friend!" is not nearly as snappy.
} 
evolution by natural selection) to see if our findings would generalize to collective entities that operate at an especially abstract level. When considered as a set, these 47 entities allow us to determine whether the same patterns hold across a diverse array of corporations, and for collectives and abstract entities more generally.

The rest of the items (29) are individuals, mostly natural phenomena. This item set builds from earlier work (H. M. Gray et al., 2007; Weisman, Dweck, \& Markman, 2017) and was developed with the Great Chain of Being in mind. The Great Chain of Being is a biologically dubious but intuitive way of classifying life on earth in terms of its distance from humanity, from protozoan to chimpanzee. Other entities in the individual category include widely discussed marginal cases of personhood (e.g. fetuses, patients in persistent vegetative states), human artifacts (e.g. robots, cars), and nonliving natural entities (e.g. rocks, clouds). This allows us to ground corporate ratings with other familiar and pertinent entities.

Our outcome variable for ANTHROPOMORPHIC PERSONHOOD was intentionally open-ended: "To what extent is ENTITY X like a person?" We also included a question that would allow us to determine whether laypeople were treating this personhood question as interchangeable with HUMANNESS: "Physically and biologically, how similar is ENTITY $\mathrm{X}$ to a human?"

To determine what factors are predictive of personhood for corporate and noncorporate entities, we constructed a set of eight measures based on oft-invoked legal and philosophical criteria for personhood (Kant, 1785/1989; Bentham, 1789/1996; Warren, 1973; Dombrowski, 1997). Half of these were related to morality (the first four items of the list below), the other half to mind. From a psychologist's perspective, moral capacities are a subset of mental capacities. But we needn't assume that participants share this view. Furthermore, even within the scope of mental capacities, morality plays a vaunted role in determining personal identity and person perception (Wojciszke, Bazinska, \& Jaworski, 1998; Goodwin, Piazza, \& Rozin, 2014; Strohminger \& Nichols, 2014). Moral goodness is particularly important to such judgments (Strohminger, Newman, \& Knobe, 2017), so we included an item to measure moral valence specifically. ${ }^{2}$ We also included items related to agency (THINKING; DECISION-MAKING; MORAL PERPETRATOR) and experience (FEELING; SELF-AWARENESS; MORAL VICTIM), as previous research indicates these are the major decomposable dimensions of morality and mind (H. M. Gray et al., 2007; K. Gray \& Wegner, 2009).

moral rights To what extent does ENTITY $\mathrm{X}$ have moral rights and responsibilities?

moral perpetrator To what extent is ENTITY X capable of wronging others?

moral victim To what extent is ENTITY X capable of being wronged by others?

moral valence Overall, to what extent is ENTITY X 'morally good or 'morally bad'?

thinking To what extent is ENTITY X capable of thinking, judgment, and reason?

\footnotetext{
${ }^{2}$ We note, in passing, the abundant evidence from everyday life that suggests a link between moral goodness and personhood. Psychopaths are seen as "soulless monsters", and good deeds are called acts of "humanity". However these stray crumbs of thought go beyond the scope of the present paper; we leave them for future research to sweep up.
} 
feeling To what extent is ENTITY X capable of emotions, feelings, and experiences?

decision-making To what extent is ENTITY $X$ capable of making decisions and acting on them?

self-awareness To what extent is ENTITY X aware that it exists?

Procedure. We recruited 800 Amazon Mechanical Turk workers ( $M d n_{\text {age }}=33,43 \%$ female, $98 \%$ American) to participate in an online study. This sample size was calculated on the basis of the number of subjects needed to achieve an average of 100 ratings per entity being judged. Descriptive statistics for all entities and measures may be found in Table S1 of the Online Supplemental Material.

In order to ensure that participants would only respond about entities they were familiar with, they were first presented with all 76 entities and asked to indicate any they did not recognize. The program randomly selected ten entities from those that were not specified in this step. These entities were presented in randomized order between subjects, to form ten total trials presented on separate pages.

In addition to the verbal label for each entity, an image that represented the entity (e.g. corporate logo, prototypical photograph of the animal) appeared at the top of the page, as a further cue to thinking.

For each entity, participants answered all ten questions as outlined above (personhood, humanness, moral rights, moral perpetrator, moral victim, moral valence, thinking, feeling, decision-making, self-awareness). Questions were on a scale from 0 ("Not at all") to 100 ("Completely"), except MORAL VALENCE, which was on a scale from -100 ("Completely bad") to 100 ("Completely good"). This bipolar scale allows for coding responses as either degree of moral goodness or (using absolute value) extremity from amorality. Questions were presented in randomized order between subjects. Once participants had answered all questions about one entity, they advanced the page to the next entity.

\section{Results and discussion}

Our initial analyses examined personhood judgments across each entity. Fitting a linear mixed-effects model with entity treated as a fixed effect and participant as a random effect, we found that participants attributed more personhood to 'an adult' $(M=94.9$, $M d n=100, S D=11)$ than to any corporation or organization, all $\beta^{\prime} \mathrm{s}>45.3, \mathrm{z}^{\prime} \mathrm{s}>14.4$, $\mathrm{p}^{\prime} \mathrm{s}<0.001$. $^{3}$ In other words, on a 100-point scale, participants attributed at least 45 fewer percentage points of personhood to any organization than to an adult. The organization with the highest personhood rating was Doctors Without Borders $(M=52.5, M d n=64.0$, $S D=35.8)$ and the corporation with the highest personhood rating was Goldman Sachs $(M=40.0, M d n=39.5, S D=36.2)$. Even this relatively personlike corporation was granted less personhood than a deceased $\operatorname{man}(M=52.3, M d n=50, S D=37.5)$.

Consistent with previous research (Knobe \& Prinz, 2008; K. Gray \& Wegner, 2010; Rai \& Diermeier, 2015; Plitt et al., 2015), we find that people attribute a nonzero amount of personhood to corporations $(M=31.0, M d n=17, S D=33.5)$. However, these artificial

\footnotetext{
${ }^{3}$ While 'adult' is not exactly a control condition, it is used as the comparison entity in these analyses as it is the canonical example of a person.
} 


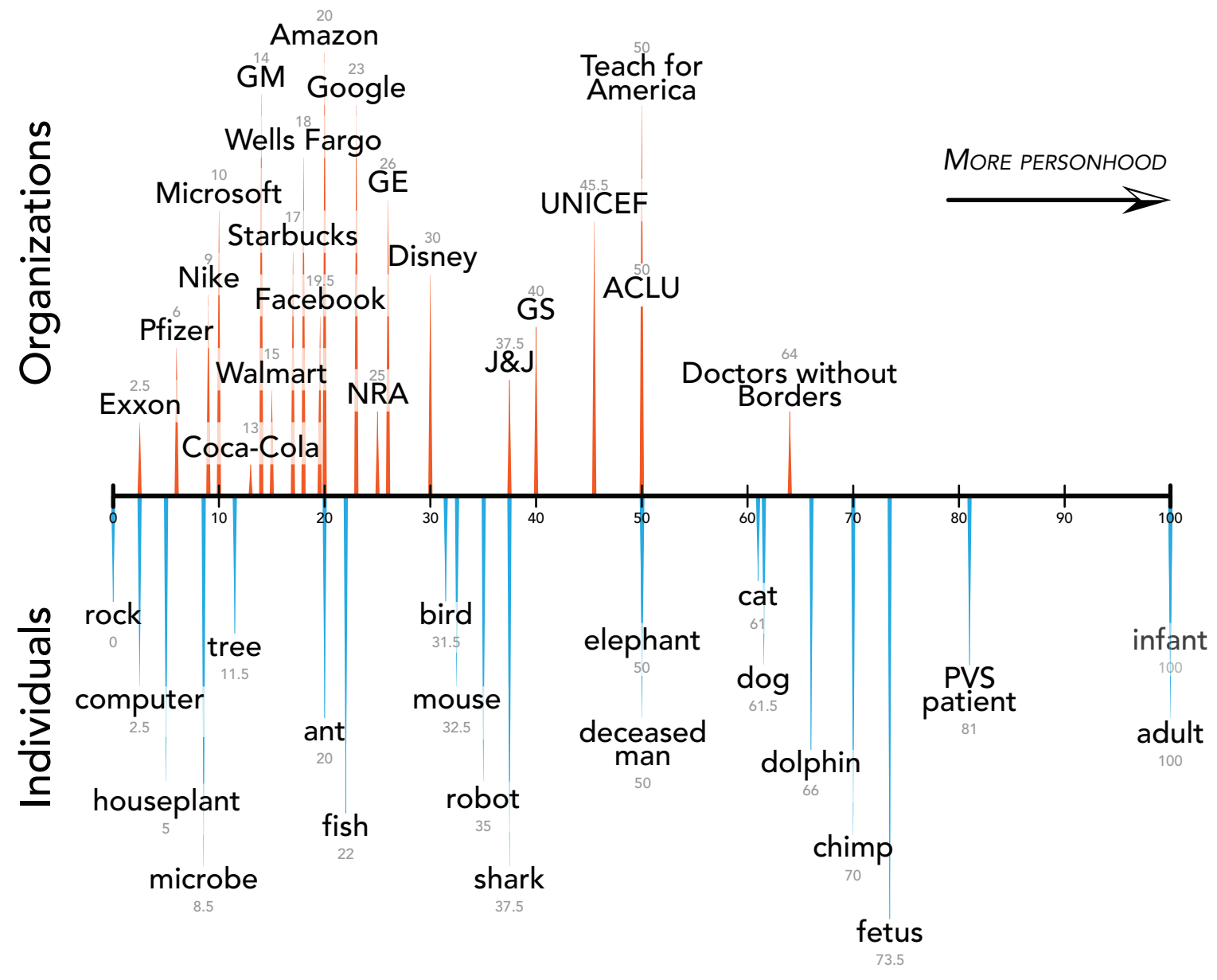

Figure 1. Number line showing the median personhood rating for 21 organizations (top, in orange) and 21 individuals (bottom, in blue). Gray values indicate median rating for that entity. Scale ranges from 0 (least personhood) to 100 (most personhood). For ease of visualization, vertical distance from axis is staggered; it is not otherwise meaningful. Figure shows a representative subset of tested items; see Table S1 for all items and descriptive statistics. Key: ACLU = American Civil Liberties Union, GE = General Electric, GM $=$ General Motors, GS = Goldman Sachs, J\&J = Johnson \& Johnson, NRA = National Rifle Association, PVS = Persistent Vegetative State.

persons are seen as having substantively less personhood than any natural person. Indeed, corporations receive less personhood than many entities that aren't generally considered candidates for legal personhood, such as cats, dogs, and elephants. A typical corporation ranks more in the range of life forms such as trees, fish, and insects (Figure 1; Table S1).

As Figure 1 amply demonstrates, there is variation in anthropomorphic personhood across organizations. What explains this variance? We fit a series of linear mixed effects models with subject-level random effects to predict personhood using the eight predictor questions for each entity (moral perpetrator, moral victim, moral valence, moral rights, 
Table 1

Standardized betas (and standard errors) for regression models predicting personhood. Rows 14 show morality-related predictors; rows 5-8 show mind-related predictors. Columns 1-8 show univariate models for each predictor; column 9 shows multivariate model using all predictors. Predictors were standardized before being added to the regression models.

\begin{tabular}{|c|c|c|c|c|c|c|c|c|c|}
\hline & \multicolumn{9}{|c|}{ PERSONHOOD } \\
\hline & (1) & (2) & (3) & (4) & (5) & (6) & (7) & (8) & (9) \\
\hline Moral rights & $\begin{array}{l}0.33^{* * *} \\
(0.01)\end{array}$ & & & & & & & & $\begin{array}{c}0.09^{* * *} \\
(0.01)\end{array}$ \\
\hline Moral perpetrator & & $\begin{array}{l}0.24^{* * *} \\
(0.01)\end{array}$ & & & & & & & $\begin{array}{c}-0.02 \\
(0.01)\end{array}$ \\
\hline Moral victim & & & $\begin{array}{l}0.32^{* * *} \\
(0.01)\end{array}$ & & & & & & $\begin{array}{l}0.06^{* * *} \\
(0.01)\end{array}$ \\
\hline Moral valence & & & & $\begin{array}{l}0.21^{* * *} \\
(0.01)\end{array}$ & & & & & $\begin{array}{l}0.06^{* * *} \\
(0.01)\end{array}$ \\
\hline Thinking & & & & & $\begin{array}{l}0.45^{* * *} \\
(0.01)\end{array}$ & & & & $\begin{array}{l}0.09^{* * *} \\
(0.01)\end{array}$ \\
\hline Feeling & & & & & & $\begin{array}{l}0.60^{* * *} \\
(0.01)\end{array}$ & & & $\begin{array}{l}0.41^{* * *} \\
(0.01)\end{array}$ \\
\hline Decision-making & & & & & & & $\begin{array}{l}0.39^{* * *} \\
(0.01)\end{array}$ & & $\begin{array}{r}-0.03^{*} \\
(0.01)\end{array}$ \\
\hline Self-awareness & & & & & & & & $\begin{array}{l}0.46^{* * *} \\
(0.01)\end{array}$ & $\begin{array}{c}0.11^{* * *} \\
(0.01)\end{array}$ \\
\hline Entities & 76 & 76 & 76 & 76 & 76 & 76 & 76 & 76 & 76 \\
\hline Subjects & 800 & 800 & 800 & 800 & 800 & 800 & 800 & 800 & 800 \\
\hline
\end{tabular}

thinking, feeling, decision-making, self-awareness). All predictor variables were standardized (given $M=0, S D=1$ ) before being entered into the regression models. In univariate models, each of the variables was positively predictive of personhood, all standardized $\beta$ 's $>0.21, \mathrm{z}^{\prime} \mathrm{s}>22.7, \mathrm{p}$ 's $<0.001$. When we fit a single model using the eight predictors of personhood, we find that most predictors retained a statistically significant positive slope, suggesting that mental and moral features each make an independent contribution to the construction of personhood (Table 1). This may also explain why non-profit organizations have greater personhood compared with corporations: higher positive moral valence $(M$ = 5.7 across corporations, whereas $M=40.1$ across non-profits; see Table S1 for by-item breakdown).

Models that replaced the personhood outcome variable with humanness delivered comparable results, suggesting that biological \& physical similarity to humans is at least partially overlapping with the folk concept of personhood (Table S2). 
Table 2

Standardized betas (and standard errors) for multivariate regression models predicting personhood across the different types of entity tested in Study 1.

\begin{tabular}{|c|c|c|c|c|c|c|c|}
\hline & \multicolumn{7}{|c|}{ PERSONHOOD } \\
\hline & Human & $\begin{array}{c}\text { Non-human } \\
\text { life }\end{array}$ & $\begin{array}{c}\text { Artifact } \\
\text { /object }\end{array}$ & $\begin{array}{c}\text { Agentic } \\
\text { abstraction }\end{array}$ & $\begin{array}{c}\text { Public } \\
\text { company }\end{array}$ & $\begin{array}{l}\text { Private } \\
\text { company }\end{array}$ & $\begin{array}{l}\text { Non- } \\
\text { profit }\end{array}$ \\
\hline Moral Rights & $\begin{array}{l}0.15^{* *} \\
(0.05)\end{array}$ & $\begin{array}{l}0.28^{* * *} \\
(0.02)\end{array}$ & $\begin{array}{l}0.14^{* * *} \\
(0.04)\end{array}$ & $\begin{array}{c}-0.02 \\
(0.06)\end{array}$ & $\begin{array}{c}0.01 \\
(0.02)\end{array}$ & $\begin{array}{c}0.01 \\
(0.04)\end{array}$ & $\begin{array}{r}-0.002 \\
(0.03)\end{array}$ \\
\hline Moral Perpetrator & $\begin{array}{r}-0.10 \\
(0.06)\end{array}$ & $\begin{array}{c}0.04^{*} \\
(0.02)\end{array}$ & $\begin{array}{l}0.15^{* * *} \\
(0.03)\end{array}$ & $\begin{array}{c}0.10^{*} \\
(0.05)\end{array}$ & $\begin{array}{r}-0.02 \\
(0.02)\end{array}$ & $\begin{array}{r}-0.04 \\
(0.04)\end{array}$ & $\begin{array}{r}-0.01 \\
(0.02)\end{array}$ \\
\hline Moral Victim & $\begin{array}{l}0.30^{* * *} \\
(0.04)\end{array}$ & $\begin{array}{c}0.0002 \\
(0.02)\end{array}$ & $\begin{array}{c}0.05 \\
(0.03)\end{array}$ & $\begin{array}{c}0.03 \\
(0.04)\end{array}$ & $\begin{array}{c}0.02 \\
(0.02)\end{array}$ & $\begin{array}{r}-0.02 \\
(0.04)\end{array}$ & $\begin{array}{c}0.02 \\
(0.02)\end{array}$ \\
\hline Moral Valence & $\begin{array}{c}0.07^{*} \\
(0.03)\end{array}$ & $\begin{array}{l}0.09^{* * *} \\
(0.02)\end{array}$ & $\begin{array}{c}0.02 \\
(0.02)\end{array}$ & $\begin{array}{c}0.01 \\
(0.04)\end{array}$ & $\begin{array}{l}0.06^{* * *} \\
(0.01)\end{array}$ & $\begin{array}{l}0.19^{* * *} \\
(0.03)\end{array}$ & $\begin{array}{l}0.07^{* * *} \\
(0.02)\end{array}$ \\
\hline Thinking & $\begin{array}{r}-0.05 \\
(0.08)\end{array}$ & $\begin{array}{l}0.21^{* * *} \\
(0.03)\end{array}$ & $\begin{array}{l}0.12^{* *} \\
(0.04)\end{array}$ & $\begin{array}{c}0.08 \\
(0.07)\end{array}$ & $\begin{array}{l}0.07^{* *} \\
(0.02)\end{array}$ & $\begin{array}{c}0.07 \\
(0.05)\end{array}$ & $\begin{array}{l}0.08^{*} \\
(0.03)\end{array}$ \\
\hline Feeling & $\begin{array}{l}0.30^{* * *} \\
(0.07)\end{array}$ & $\begin{array}{l}0.17^{* * *} \\
(0.03)\end{array}$ & $\begin{array}{l}0.20^{* * *} \\
(0.04)\end{array}$ & $\begin{array}{l}0.59 * * * \\
(0.05)\end{array}$ & $\begin{array}{l}0.42^{* * *} \\
(0.02)\end{array}$ & $\begin{array}{l}0.63^{* * *} \\
(0.04)\end{array}$ & $\begin{array}{l}0.47^{* * *} \\
(0.03)\end{array}$ \\
\hline Decision-making & $\begin{array}{r}-0.01 \\
(0.08)\end{array}$ & $\begin{array}{c}0.02 \\
(0.03)\end{array}$ & $\begin{array}{c}0.08^{*} \\
(0.04)\end{array}$ & $\begin{array}{c}0.08 \\
(0.06)\end{array}$ & $\begin{array}{c}0.04 \\
(0.02)\end{array}$ & $\begin{array}{c}0.03 \\
(0.05)\end{array}$ & $\begin{array}{c}0.01 \\
(0.03)\end{array}$ \\
\hline Self-awareness & $\begin{array}{c}0.16^{*} \\
(0.07)\end{array}$ & $\begin{array}{c}0.06^{*} \\
(0.02)\end{array}$ & $\begin{array}{l}0.25^{* * *} \\
(0.04)\end{array}$ & $\begin{array}{c}0.05 \\
(0.06)\end{array}$ & $\begin{array}{l}0.17^{* * *} \\
(0.02)\end{array}$ & $\begin{array}{c}0.06 \\
(0.05)\end{array}$ & $\begin{array}{l}0.21^{* * *} \\
(0.03)\end{array}$ \\
\hline $\begin{array}{l}\text { Entities } \\
\text { Subjects }\end{array}$ & $\begin{array}{c}6 \\
479\end{array}$ & $\begin{array}{c}17 \\
758\end{array}$ & $\begin{array}{c}6 \\
488\end{array}$ & $\begin{array}{c}4 \\
303\end{array}$ & $\begin{array}{c}25 \\
793\end{array}$ & $\begin{array}{c}5 \\
357\end{array}$ & $\begin{array}{c}13 \\
692\end{array}$ \\
\hline
\end{tabular}

In a further set of analyses, we sought to determine whether these findings are consistent across entity type. These models reveal some differences across entity type: for instance, moral patiency was a strong predictor of personhood for humans, but no other entity. Moral goodness was predictive of personhood for organizations, but not artifacts (Table 2). These patterns may be driven in part by differences in predictor rating variance across entity type, although this study design does not allow us to draw strong conclusions. Nonetheless, one consistency across entities is that moral variables and mental variables remain crucial to attributions of personhood no matter the entity. Sentience ("FEELING") is a particularly strong predictor across all entity types (Tables 1,2).

Our data is in broad agreement with prior research, which has found that corporations are seen as lower on experience than agency (Knobe \& Prinz, 2008; K. Gray \& Wegner, 2010; Phelan et al., 2013; Rai \& Diermeier, 2015; Table S1). However, this study adds a twist to what has come before. While corporations are lower in experience overall, there is considerable variation between corporations, and a corporation's ability to feel is a much stronger predictor of personhood than its ability to think (Table 2). 


\section{Study 2}

While working on the revisions to this paper, the opportunity for a natural experiment presented itself. ${ }^{4}$ Like many researchers, we noticed that a pandemic was occurring in 2020. Multiple pharmaceutical companies developed a COVID-19 vaccine during this period. Fortuitously, two of these companies, Pfizer and Johnson \& Johnson, were measured in Study 1. That study was run in 2018, when the virus was still just a twinkle in a bat's eye.

One of the insights generated by Study 1 is that corporations that are seen as more morally good are also seen as more personlike. The aim of the present study is to establish whether this relationship holds in the wake of a particular, conspicuous act of corporate good. Did the development of a vaccine by Pfizer and Johnson \& Johnson improve their moral reputation (providing, as it would, an immense, once-in-a-generation ${ }^{5}$ societal good), and in turn, increase their perceived personhood?

To answer these questions, we ran the study again, this time using participants living in a pandemic world. In order to maximize our ability to make valid comparisons between the data from 2018 (Study 1) and 2021 (Study 2), no changes were made to the essential study design or participant recruitment source. A major reason for this is that ratings can vary systematically depending on implicit comparisons with what else is being rated (Rogers, 1941; Hunt, 1941; Brown, 1953; Sherif, Taub, \& Hovland, 1958; Slovic, 1967; Tversky \& Kahneman, 1974; Hsee, Loewenstein, Blount, \& Bazerman, 1999). So even though we were chiefly interested in judgments for corporations, we collected ratings of all the entities used in the previous study.

Study 2 was run in January 2021, when Pfizer's vaccine rollout was well underway, and just after it was announced that Johnson \& Johnson had an effective vaccine. Knowledge of the Johnson \& Johnson vaccine may not have penetrated to the public broadly by this time, allowing us to compare the two companies directly. The only thing more convenient would have been if the original study included a pharmaceutical company that did not develop a COVID vaccine; alas, no researcher's luck is infinite.

\section{Methods}

We recruited 1009 CloudResearch (TurkPrime) workers ( $M d n_{\text {age }}=37,47 \%$ female, 97\% American) to participate in an online study. We aimed to have comparable demographics and at least the same power as before, so we recruited from the same platform, with a slightly larger sample size.

The study procedure was identical to Study 1 in all respects except the following.

After completing all ratings for entities, but before collecting demographics information, participants answered two questionnaires, one about Pfizer, the other about Johnson \& Johnson. Participants were instructed to respond without looking up the answers. They only received a questionnaire if they had indicated they were familiar with the company at the start of the study. (This measure, also used in Study 1, ensured that we only collected responses about entities with which participants were familiar.) Whether participants answered the questionnaire about Pfizer first or last was randomized between subjects.

\footnotetext{
${ }^{4}$ We thank the editor, Daniel Bartels, for this suggestion.

${ }^{5} \mathrm{Ha}$ ha ha ha. We hope.
} 
The questionnaire had a funnel design, with three questions that started with general knowledge about the company and ended with a pointed question about awareness of the company's vaccine. The funnel structure was to reduce, or at least account for, socially desirable responding as much as possible. First, we asked a free response: what kind of company was Pfizer (or Johnson \& Johnson)? Then, we asked (again as free response) what is something that this company is known for? Finally, on a separate page, we asked if they were aware that the company had discovered an effective COVID-19 vaccine. Responses to this question were collected as a yes-or-no binary choice.

By placing these questionnaires at the tail end of the study (participants cannot return to previous pages), we ensure that they have no impact on the other measures of interest.

\section{Results}

As predicted, more people were aware of Pfizer's vaccine $(93 \%)$ than Johnson \& Johnson's (43\%) at the time of the study. For the sake of simplicity, we adopt an intention to treat framework and assume that everyone was aware of the Pfizer vaccine and that no one was aware of the Johnson \& Johnson vaccine; we use intention to treat in part because it is the most conservative approach (some people being aware of the Johnson \& Johnson vaccine can only reduce our effect estimate) and in part because we want to avoid conditioning on features like awareness of current events which might be correlated with views on personhood in important but unknown ways.

We fit two different models, one using all for-profit corporations as our control and one using Johnson \& Johnson as our control. Both of these models use a difference-indifferences approach to estimate how the distribution of the Pfizer vaccine affected personhood evaluations and allow us to net out any broad (non-vaccine-related) changes in how people judge the personhood of corporations over time. We did observe a sizable reduction in personhood judgments from pre-period to post-period (from $M=31$ to 23 on a 100-point scale).

When we use all corporations as our control, we find that non-Pfizer companies were judged as having less anthropomorphic personhood in the post-period $(\beta=-7.30$, $\mathrm{SE}=0.76, \mathrm{p}<0.001)$ while Pfizer saw a non-significant increase in personhood attribution $(\beta=1.86, \mathrm{SE}=4.09, \mathrm{p}=0.455)$. This left us with a significant difference-in-differences estimate $(\beta=9.14, \mathrm{SE}=4.16, \mathrm{p}=0.028)$ such that personhood attributions of Pfizer went up 9.14 points net of the average change among corporations from the pre- to post-vaccine period.

Our more conservative test uses the same logic, but relies on Johnson \& Johnson as the control as it is both a pharmaceutical company and had a vaccine in the pipeline, albeit somewhat behind the Pfizer vaccine. Across periods, Johnson \& Johnson saw a significant reduction in personhood attributions $(\beta=-13.03, \mathrm{SE}=4.11, \mathrm{p}=0.002)$ while Pfizer saw a non-significant increase (see above). As was the case with the comparison to all corporations, net of changes to personhood attributions in Johnson \& Johnson, Pfizer saw a significant increase in personhood judgments $(\beta=14.89, \mathrm{SE}=5.86, \mathrm{p}=0.012)$.

Both models suggest that introducing a COVID-19 vaccine helped to resist a general reduction in personhood attributions to corporations that occurred during the pandemic. 
There are limitations to what we can infer from such a study design. We can never really be sure if the changes observed were caused by the vaccine or something else. Even though we measure awareness of the vaccine, and can use that as a predictor, we cannot rule out a hidden third variable. Nonetheless, the natural experiment design provides a rare chance to discover if the factors observed in Study 1 are relevant to changing perceptions of corporate personhood over time. And it seems that they are.

\section{Study Set 3}

Studies 1 and 2 found that having mental and moral features predicts corporate anthropomorphization. In follow-up experiments, we aimed to test whether this relationship was causal. We also sought to determine whether having these human features increases willingness to grant legal personhood to corporations.

In Study 3a, we investigate whether a corporate mission statement that uses mental language (as opposed to computational language) to describe the company will result in greater endorsement of legal personhood for that company. Study $3 \mathrm{~b}$ follows a similar logic, but manipulates whether the company has primarily moral (as opposed to profitbased) goals.

Studies $3 \mathrm{a}$ and $3 \mathrm{~b}$ were designed to be low in experimenter demand. Participants only answer a single question, about endorsement of rights for the company.

In a separate norming study (described below), we pre-test these mission statements to confirm that they manipulate judgments about the company on the relevant featuresmind, morality, and anthropomorphism. This allows us to pursue the low-demand singlequestion design employed in Studies $3 a$ and $3 b$.

\section{Norming study}

Methods. 599 participants were recruited from the online platform Prolific (97\% American, $44 \%$ female, $\left.M d n_{\text {age }}=28\right)$.

In a 2 (mind, morality) $\times 2$ (high, low) between-subjects design, we presented participants with one of four corporate mission statements, each describing a different kind of company.

The mind-related mission statements described a company whose goals related to thought and reason (high mind) or to computations and algorithms (low mind).

\section{Low mind}

Our goal is to use cutting-edge cyber engineering to model data, big and small. The cornerstone of our mission is to use algorithms, machine learning, and other automated technologies to make calculations that solve scientific problems. It is up to us to change the world by advancing industrial solutions through computational technology. All other goals are secondary.

\section{High mind}

Our goal is to think deeply, solve problems creatively, and exemplify the highest intellectual achievement in all of our endeavors. The cornerstone of our mission is to approach questions using the utmost curiosity, imagination, and 
wisdom. It is up to us to change the world by taking decisive action through judgment and reason. All other goals are secondary.

The morality-related mission statements described a company whose goals prioritized social responsibility (high morality) or profits (low morality). Prior research has shown that profit-seeking motives by companies are implicitly understood as immoral (Bhattacharjee et al., 2017).

\section{Low morality}

Our goal is to deliver superior returns to our shareholders by tirelessly pursuing new growth opportunities while continually improving our profitability. Whenever possible, we aim to generate growth responsibly. Nonetheless, the cornerstone of our mission is to deliver maximum profits and growth to our shareholders. All other goals are secondary.

\section{High morality}

Our goal is to embody social responsibility, philanthropy, sustainability, and the highest standards of integrity in all of our business practices. Whenever possible, we aim to generate profits for our shareholders. Nonetheless, the cornerstone of our mission is to serve and enhance the communities in which we work and live and the society on which we depend. All other goals are secondary.

To increase engagement in the task, after reading the mission statement participants gave a written response to the following two questions: "In your own words, what is Acme's priority?" and "What is a real company that might have a similar mission statement as Acme's?"

Participants then answered all of the following questions, presented in randomized order between subjects:

morality To what extent do you think Acme acts in a morally good or morally bad way?

mind To what extent do you think Acme has a mind?

anthropomorphism To what extent does Acme seem like a person?

entitativity ${ }^{6}$ To what extent does Acme seem like a separate entity from the individuals it is made of? ${ }^{7}$

\footnotetext{
${ }^{6}$ Intelligent minds disagree about the spelling of this word, and no one likes pronouncing it. The article coining the term spells it entitativity (Campbell, 1958), though some subsequent papers, in a zealous bid for efficiency, abbreviate it to entitivity (see footnote 2 of Abelson, Dasgupta, Park, \& Banaji, 1998). Even Campbell wrings his hands over the excess syllabicity, only yielding to what he considers grammatical necessity (1958, footnote 2). As of December 2021, entitivity yields 644 Google Scholar results, whereas entitativity yields 7790. When in doubt, let the robots decide.

${ }^{7}$ We use the term 'entitativity' in its original sense. Entitativity is based on the idea that Gestalt principles can be applied to the perception of social groups: does the collective appear to spring into existence, abstracted away from its constituent parts (Campbell, 1958)? While this remains the standard definition (Abelson et al., 1998; Haslam, Holland, \& Karasawa, 2013), some empirical research operationalizes entitativity as the Gestalt antecedents of entitativity (e.g. common fate) rather than entitativity itself (e.g. Waytz \& Young, 2012).
} 
prestige How much prestige do you think is associated with working at Acme?

All questions were answered on a scale from 0 ("Not at all" / "None") to 100 ("Completely" / "A lot"), except the morality question, which was answered on a scale from -100 ("Completely bad") to 100 ("Completely good").

Results and discussion. A paired t-test finds that the company described with mental terms was judged to have more mind $(M=47.5, S E=2.89)$ than the company that was not $(M=36.3, S E=2.38 ; t(275)=3.0, p=0.003, \mathrm{~d}=0.35)$. The company described with mental terms was also judged as more personlike $(M=39.3, S E=2.44)$ than the opposing company $(M=26.5, S E=2.12 ; t(281)=4.0, p<0.001, \mathrm{~d}=0.46)$.

Likewise, the company described as prosocial was judged to be more morally good $(M=41.2, S E=3.37)$ than the company that was described as profit-seeking $(M=-14.7$, $S E=4.42 ; t(277)=10.1, p<0.001, \mathrm{~d}=1.17)$. The company described as prosocial was also judged as more personlike $(M=39.4, S E=2.45)$ than its counterpart $(M=24.5, S E=2.24$; $t(299)=4.4, p<0.001, \mathrm{~d}=0.51)$.

Supplemental analyses give a fuller picture of the nature of these stimuli. Although we did not have any specific predictions about these comparisons, we report them here for the sake of completeness. The company described with mental terms was judged to be more morally good $(M=33.9, S E=3.58)$ than the company that was not $(M=20.8$, $S E=3.14 ; t(283)=2.8, p=0.006, d=0.32)$. The company described as prosocial was not judged to have any more mind $(M=42.6, S E=2.55)$ than the company that was described as profit-seeking $(M=39.7, S E=2.70 ; t(298)=0.77, p=0.44)$. This asymmetry opens up the possibility that the mind manipulation also functions as a morality manipulation. We address this ambiguity in a supplemental study (see Study S1 of Online Supplemental Materials).

The prestige question was included to check whether the mission statements elicited positive evaluations in domains outside of the targeted one. The company described with mental terms was not judged to be any more prestigious to work at $(M=69.9, S E=1.86)$ than the company that was not $(M=71.6, S E=1.51 ; t(272)=0.71, p=0.48)$. However the company described as prosocial was judged to be more prestigious to work at $(M=62.8$, $S E=1.77)$ than its counterpart $(M=52.2, S E=2.27 ; t(280)=0.77, p<0.001, \mathrm{~d}=0.42)$.

The mission statement did not increase entitativity judgments between the high mind $(M=46.3, S E=2.39)$ and low mind conditions $(M=50.8, S E=2.31 ; t(291)=1.35, p=$ $0.18)$. It did however reliably change the entitativity judgments between the high morality $(M=42.6, S E=2.26)$ and low morality conditions $(M=50.3, S E=2.50 ; t(295)=2.24, p=$ $0.03, \mathrm{~d}=0.26)$.

In sum, these mission statements elicit the predicted within-domain belief manipulations of mind and morality. We also uncover evidence for the causal relationship between apparent mental/moral features and corporate anthropomorphism.

\section{Study 3a}

Methods. 301 participants were recruited from the online platform Prolific (99\% American, $47 \%$ female, $M d n_{\text {age }}=28$ ).

Participants were presented with either the high or low mind mission statement. As in the pilot study, after reading the mission statement, they summarized the company's 


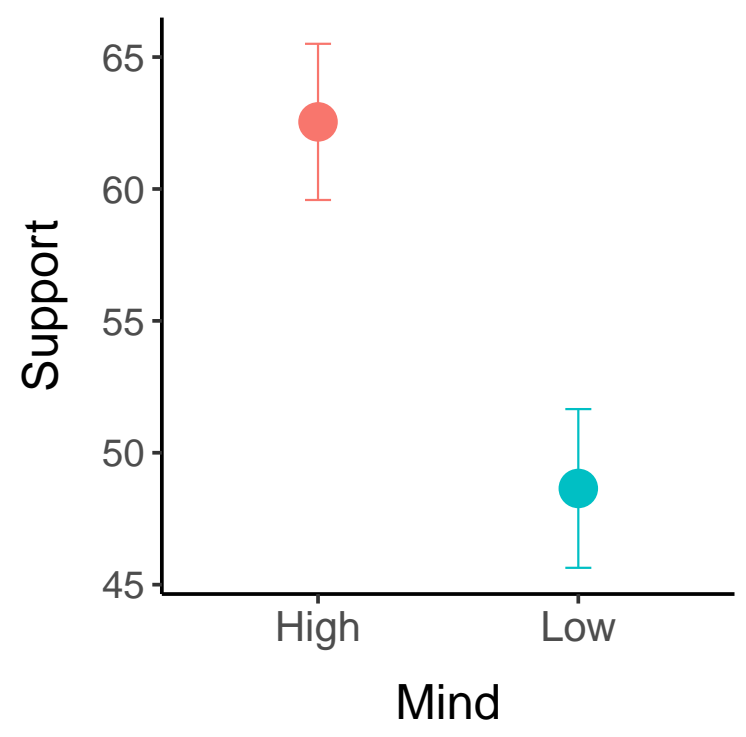

Figure 2. Differences in degree of overall support for legal personhood for companies described in mental terms or not. Bars represent the standard error.

goals, and named a real company which might have a similar mission as Acme's.

Participants then responded to a single question on their general support for juridical personhood for this company: "To what extent would you support granting certain human rights to this company (such as free speech, voting, privacy, a fair trial)?" Responses were measured on a sliding scale from 0 ("Not at all") to 100 ("Completely").

Results and Discussion. A paired t-test revealed that when the company was described with mental terms, people were more supportive of granting it human rights $(M=$ $62.5, S E=2.96)$ than when it was not $(M=48.6, S E=3.01 ; t(299)=3.3, p=0.001, d=0.40)$; see Figure 2. Thus, we find the predicted causal relationship between mental attributes and legal personhood.

Because the norming study found that the "high mind" corporation was also seen as more morally good, we ran an additional study to determine whether the observed effect could be entirely accounted for by differences in perceived moral goodness (Study S1 in Online Supplemental Materials). Study S1 replicated the findings of Study 3a. Once participant-level rating for the company's moral goodness is statistically accounted for, the degree of effect on legal personhood is reduced, but remains statistically significant. Thus we conclude that the main effect of Study 3a cannot purely be attributed to inferred moral differences between the two corporations, although this is a contributing factor.

\section{Study $3 b$}

This study had two aims. The first was to see whether the effect uncovered in Study 3a would also show up for the mission statement where the company's morality was manipulated. We also wanted to see if the effect would hold when we measured support across specific human rights. 


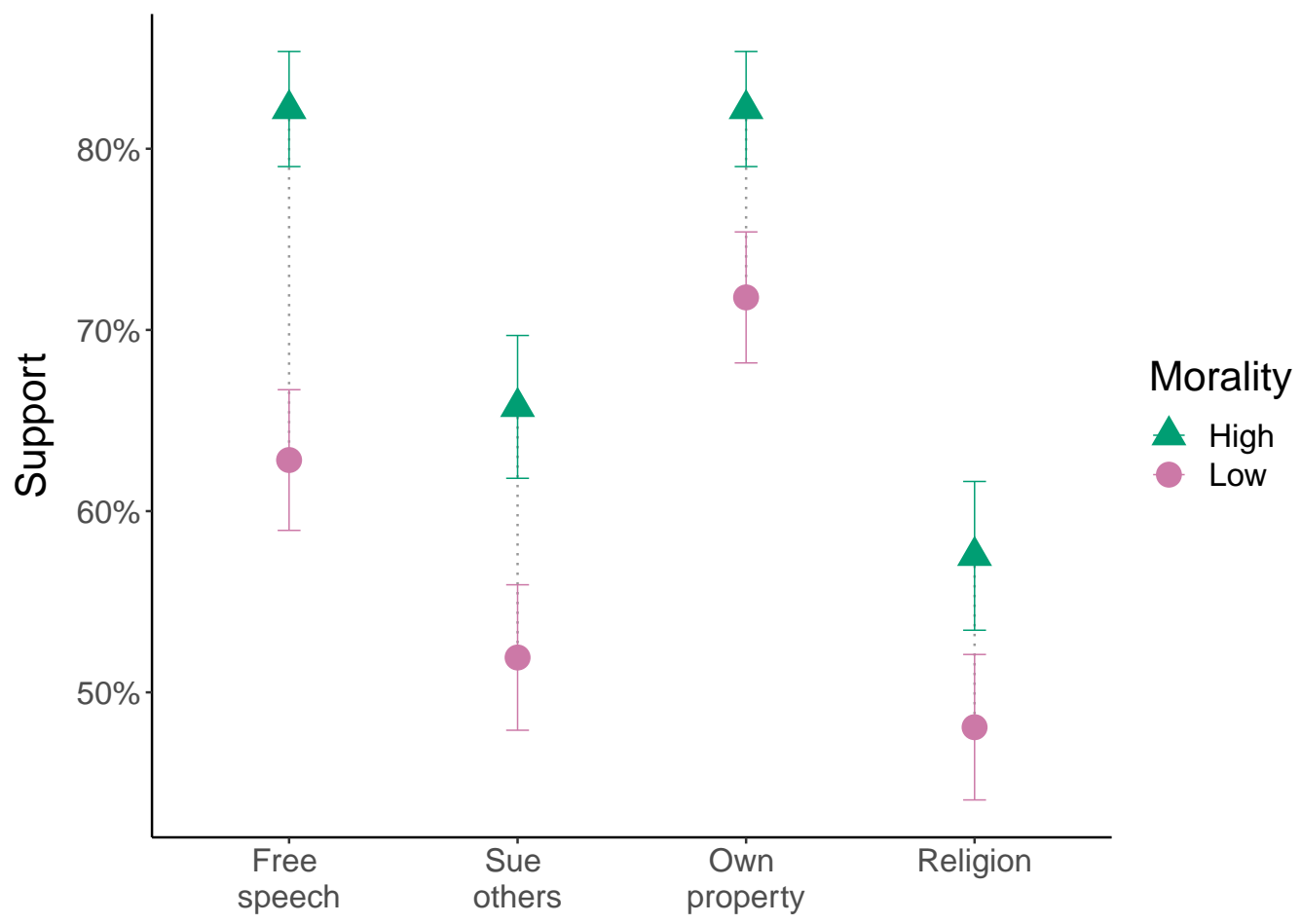

Figure 3. Percentage of support for legal personhood for companies described as having prosocial goals or not, across four different human rights. Bars represent the standard error.

Methods. 302 participants were recruited from the online platform Prolific (98\% American, $51 \%$ female, $M d n_{\text {age }}=28$ ).

The design of Study $3 b$ was identical to that of Study 3a, with the following two changes. Participants were shown the pair of corporate mission statements that elicit high and low degrees of assessed morality (see norming study above). To measure support for legal personhood, participants were presented with four possible rights (the right to free speech, sue others for damages, own property, and religious freedom) and asked to select as many as they would support granting to the company (participants could also select 'None'). This response was treated as four binary within-subject scores per each participant.

Results and discussion. A mixed-effects logistic regression model, with participant and civil right entered as random effects, found that people supported a higher percentage of civil rights for the company with prosocial goals $(M=71.2 \%, S E=1.86)$ than the company with profit-seeking goals $(M=58.7 \%, S E=1.97$; standardized $\beta=-1.01, S E$ $=0.29, z=3.51, p<0.001)$; see Figure 3 .

Increasing the salience of a corporation's moral goals leads to increased support for its legal personhood. This effect generalizes whether asking about rights in general (Study 3a) or specific legal rights (Study $3 b$ ). 


\section{Study 4}

The aim of Study 4 was to expand upon the insights uncovered by Study Set 3. Study 4 offers a conceptual replication using different materials, which will allow us to draw inferences about robustness and generalizability. This study also employs a minimal pair design, so that the results cannot be attributed to incidental differences between the conditions. Finally, this study uses within-subject measures to allow for more direct inferences about how perceptions of different company attributes influence each other.

\section{Methods}

Materials. We employed an experimental manipulation using a debate task. In a $2 \times 2$ between-subjects design, participants were asked to act as if they were on a debate team, and generate arguments in favor or against one of the following viewpoints: "Overall, corporations act in a moral way" or "Corporations have minds". The results of Study 1 revealed that both mind predictors and morality predictors are related to personhood. Therefore the prompts were designed to be a distillation of these two basic concepts, morality and mind.

The debate task was designed to prime, or make salient, arguments in support of each position. Participants defended this position rather than simply enumerating reasons (or passively taking in information), as previous research has shown that advocation for a side, even if arbitrarily assigned, is a powerful way of getting advocates to change their minds (Festinger, 1962; Higgins \& Rholes, 1978; Melnikoff \& Strohminger, 2020). An important moderator for such effects is how entrenched the prior belief is. This may be a relevant factor for the present findings, but as we did not ask participants to report how convincing they found their own arguments, we cannot speak to it directly.

Procedure. Participants were 883 Amazon Mechanical Turk workers $\left(M d n_{\text {age }}=33\right.$, $44 \%$ female). In order to motivate engagement with the debate task, the instructions specified that participants would only be paid if they responded to the prompt, using their own words (as opposed to typing gibberish, or copying text from another source).

Debate prompt (morality or mind) and position (pro or con) were randomly assigned. Participants saw only one debate prompt, and they could not choose which position to respond to. Participants had to write an essay of no fewer than 50 words in support of their assigned position. They could not proceed to the next page until this minimum word limit had been reached. See Supplement for a full description of task instructions and prompts.

After completing this task, participants were asked about their personal beliefs regarding corporations. We measured opinions of whether corporations are good or bad, and whether corporations have minds. These two questions served as a manipulation check: did the debate task succeed in biasing participants to be more likely to agree with the side they had just argued in favor of? We also asked how similar corporations are to persons (anthropomorphic personhood), whether corporations are separate from the individuals they are made of (entitativity), and whether corporations should be held responsible for their actions (moral responsibility).

These questions were presented on a scale of 0 ("Not at all") to 100 ("Completely"), except for the measure of corporate goodness, which was anchored at -100 ("Completely 
bad") to 100 ("Completely good"). We also asked which of nine civil rights corporations should have (binary response: yes or no; item order randomized between subjects). These rights vary in their legal status and contentiousness, but all have been discussed as potential corporate rights: the right to free speech, vote, privacy, fair court trial, sue others for damages, plead the fifth (i.e. not self-incriminate), enter contracts, own property, and religious freedom. Responses to this question were scored 0-9, representing the total number of rights the participant thought corporations should be granted. Order of these six questions was randomized between subjects. Afterwards, basic demographics information was collected (sex, age, political orientation).

Analytic strategy. We aimed for a sample size of 200 subjects per cell, after exclusion.

Participants who cheated on the debate task were excluded. Cheating was defined narrowly: those who plagiarized text from a source on a related topic (as confirmed by a web search), or who did not respond to the debate prompt. ${ }^{8}$ We did not exclude participants who provided poorly-reasoned or illogical arguments, as we believed the efficacy of the prime would come from inhabiting an overall stance, rather than generating sensible arguments. Furthermore, the boundary between "good argument" and "bad argument" is a porous one, making it difficult to define precise exclusion criteria. Because the exclusion criteria we used were concrete, there was no need for multiple raters or other formal coding processes. ${ }^{9} 128(14.5 \%)$ responses were excluded without analysis, leaving 755 participants.

\section{Results and discussion}

Responses on the debate task were quite varied. We include some examples here to give a sense of the types of responses participants wrote; the full set of responses may be accessed on the OSF repository at: https://osf .io/e2g7v/.

Pro mind "Corporations definitely have minds. A person, or a group of people make up a corporation. A corporation could not exist without people present. People have minds, and those people make up corporations. For instance, NASA itself knows how to make a space shuttle, yet no single NASA employee knows exactly how. It is only as a collective corporation that the space shuttle can be built. Therefore, a corporation does, indeed, have a mind."

Con mind "The mind implies you have the ability to make decisions or respond to your environment. A corporation is not able to respond to the environment it operates within. Only the people within the corporation have this ability. They may steer the corporation but the corporation has not independent ability to make a logical decision."

\footnotetext{
${ }^{8}$ At the time these studies were run, entering the debate keywords into a search engine did not bring up any webpages that directly addressed the debate prompt. This means that plagiarists were never quite performing the task- a dead giveaway of cheating, which could be confirmed by a web search. Unusually articulate responses were also checked. For the latter case, cheating was rarely discovered, and the researchers were forced to conclude that their participants were eloquent.

${ }^{9}$ The tedious process of coding these many hundreds of responses was performed by N.S., and she would like credit for the most mind-numbing sixteen hours of her life.
} 
Pro morality "A lot of corporations in today's work force in the United States have taken great strides to act in a moral fashion. One such way is they will often donate large sums of money to various humanitarian causes. Other ways is to provide many health and wellness programs to their employees and employee's families."

Con morality "All corporations care about is making a profit. They pay low wages to all their front line employees while the CEOs make way way more than they need to. So many employees end up needing public assistance because of low wages. Corporations also cause a great deal of pollution."

The manipulation check revealed that the debate task altered personal beliefs regarding the debate prompt. Participants who were assigned to defend the stance that corporations have minds subsequently endorsed the belief that corporations have minds to a greater degree $(M=49.5, S E=2.43)$ than those asked to defend the opposing stance $(M=16.6, S E=1.54$; pairwise t-test: $t(340)=11.5, p<0.001, \mathrm{~d}=1.14)$. Likewise, those asked to defend the view that corporations are good believed that corporations are morally superior $(M=6.76, S E=4.07)$ than those asked to defend the opposing view $(M=-34.9, S E$ $=3.12 ; t(331)=11.5, p<0.001, \mathrm{~d}=0.86)$. These effects did not consistently translate across debate task, such that those asked to defend the view that corporations are morally good were no more liable to believe that corporations had minds $(M=43.1, S E=2.67)$ than those arguing against $(M=40.0, S E=2.78 ; t(356)=-0.82, p=0.41, d=-0.09)$. Defending the view that corporations have minds had a reliable, though comparatively modest, impact on personal belief that corporations are less morally bad $(M=-9.02, S E=2.92)$ compared with defending the view that corporations are mindless $(M=-.19 .1, S E=2.76 ; t(395)=2.51$, $p=0.01, \mathrm{~d}=0.25)$.

Having confirmed the efficacy of the debate task, we tested whether these manipulations impacted anthropomorphic personhood attributions. Participants in the pro mind condition believed that corporations have more personhood $(M=44.7, S E=2.28)$ than those in the con condition $(M=19.9, S E=1.65$; linear regression: standardized $\beta=0.40, t=$ $8.75, p<0.001)$, and those in the pro moral goodness condition believed that corporations have more personhood $(M=45.7, S E=2.43)$ than those in the con condition $(M=33.1, S E$ $=2.30$; standardized $\beta=0.20, t=3.77, p<0.001)$. Inducing the belief that corporations have a mind, or are morally good, makes them seem more personlike (Figure 4).

The mind prime led to starker differences between the pro and con conditions than the morality prime. This was the case both for anthropomorphization (interaction effect: standardized $\beta=-0.40, t=-2.83, p=0.005$ ) and rights granted (interaction effect: standardized $\beta=-0.31, t=-2.15, p=0.03$ ). This could be due to participants entering the study with firmer beliefs about corporate morality than corporate mindedness.

Individual differences in belief reinforce the findings uncovered by the debate task manipulation. Within each of the four conditions, belief that corporations have minds positively predicts belief that they are similar to people (pro mind condition: standardized $\beta=0.79, S E=0.04, t=18.1, p<0.001$; con mind condition: standardized $\beta=0.69$, $t=13.2, p<0.001$; pro morality condition: standardized $\beta=0.71, t=13.3, p<0.001$; con morality condition: standardized $\beta=0.66, t=11.9, p<0.001)$. Belief that corporations are morally good also positively predicts corporate anthropomorphism (pro mind condition: standardized $\beta=0.44, t=7.0, p<0.001$; con mind condition: standardized $\beta=0.17, t=2.43$, 


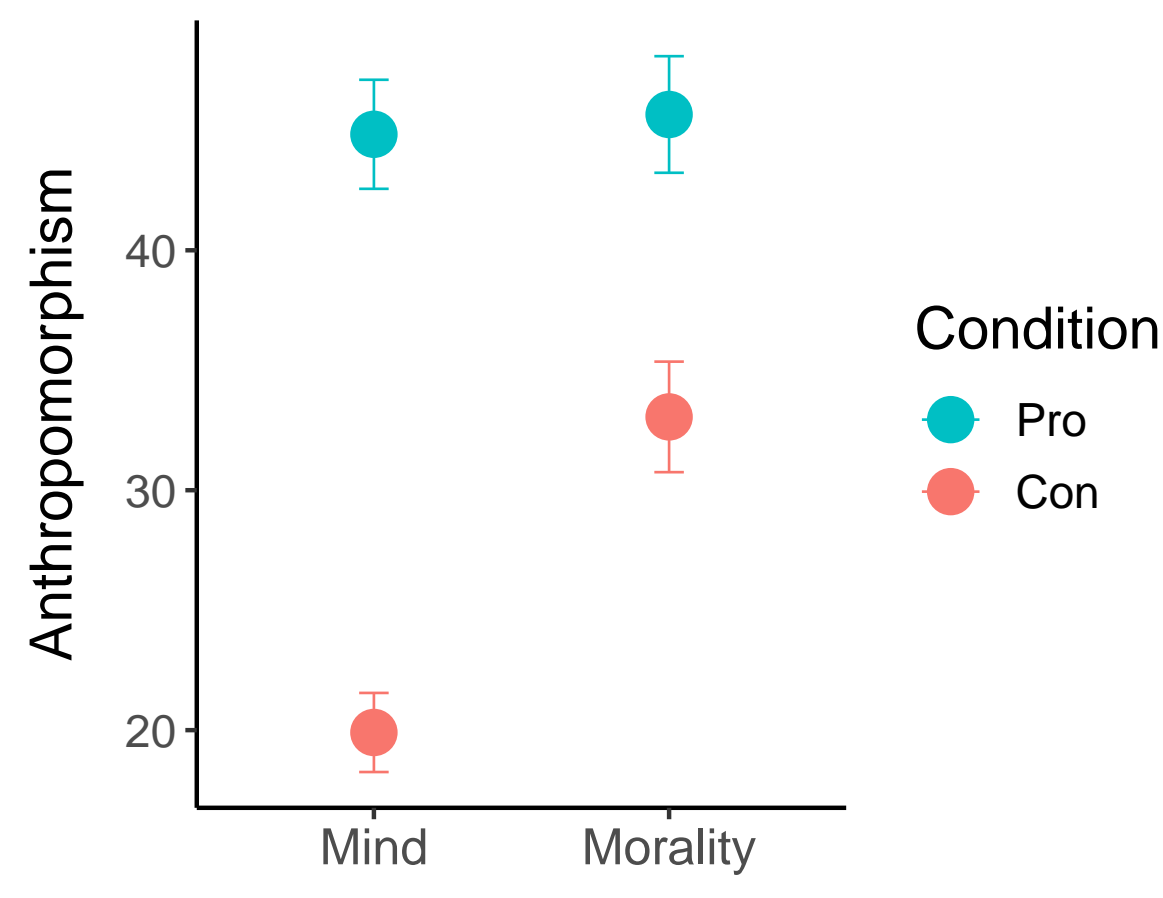

Figure 4. The effect of priming pro/con arguments that corporations have minds, or are morally good, on personal beliefs that corporations are like people. Bars represent the standard error.

$p=0.02$; pro morality condition: standardized $\beta=0.40, t=5.70, p<0.001$; con morality condition: standardized $\beta=0.27, t=3.78, p<0.001)$. Thus, stable beliefs about corporations independently show the same pattern as beliefs induced by the transitory debate manipulation. These results, which portray beliefs about corporations in general, are consistent with those in Studies 1 and 2, which portray beliefs about particular corporations.

Next, we sought to determine whether these manipulations impacted willingness to attribute legal personhood to corporations. Those in the pro mind condition believed that corporations should be granted more rights $(M=5.18, S E=0.18)$ than those in the con condition $(M=3.83, S E=0.21$; total effect: $\beta=1.35, S E=0.27, t=5.00, p<0.001)$. In other words, on average participants were willing to grant more than one additional right to corporations as a result of this simple manipulation. Perceived personhood partially mediated this effect. Nonparametric bootstrap analysis using 1000 Monte Carlo simulations (Preacher \& Hayes, 2008) reveals that the indirect effect through perceived personhood $(\beta=0.77, p<0.001,95 \% \mathrm{CI}=[0.52,1.07])$ explains $57 \%$ of the total effect from the mind condition to beliefs about corporate rights (direct effect: $\beta=0.58, p=0.03,95 \% \mathrm{CI}=[0.07$, 1.14]). While not definitive, this mediation model supports a commonsense explanation for how this effect could work: namely, that being seen as having a mind increases legal personhood not just for any reason, but because it is considered a personlike trait.

Those in the pro moral goodness condition also believed that corporations should be granted more rights $(M=5.30, S E=0.18)$ than those in the con condition $(M=4.79$, 
$S E=0.19$; total effect: $\beta=0.51, S E=0.26, t=1.94, p=0.05)$. The smaller effect size on rights attributions under the morality prime is consistent with our finding that the morality prime influences personhood judgments less than the mind prime. When perceived personhood is included as a mediator, the effect from morality prime to rights attributions drops from significant (indirect effect: $\beta=0.25, p<0.001,95 \% \mathrm{CI}=[0.10,0.44]$ ) to nonsignificant (direct effect: $\beta=0.26, p=0.33,95 \% \mathrm{CI}=[-0.31,0.77]$ ). This explains $50 \%$ of the total effect from the morality condition to beliefs about corporate rights, again suggesting that anthropomorphic personhood is an underlying force driving the judgments of legal personhood. The primes were similarly effective in changing support across different legal rights (Figure 5).

Legal personhood is primarily determined by rights, but this definition can expand to include moral responsibility. We found that those in the pro mind condition believed that corporations should be held more responsible for their actions $(M=88.7, S E=1.38)$ than those in the con condition $(M=78.7, S E=2.17$; linear model: standardized $\beta=0.19$, $t=3.92, p<0.001)$. However, there was no difference between the pro $(M=91.0, S E=$ 1.18) and con conditions for moral goodness $(M=91.7, S E=1.40$; standardized $\beta=-0.02$, $t=0.38, p=0.70)$. When all participants are included in the same model, this reveals a significant interaction effect between topic and side (standardized $\beta=-0.24, t=3.34, p$ $<0.001$ ), suggesting that people are unwilling to let misbehaving corporations off the hook.

Entitativity judgments were not affected by either prime, whether pro mind $(M=$ $45.9, S E=2.26)$ or against $(M=44.6, S E=2.47 ; t(390)=-0.45, p=0.65, \mathrm{~d}=-0.05)$; pro morality $(M=47.4, S E=2.23)$ or against $(M=42.0, S E=2.29 ; t(356)=-1.69, p=0.09, \mathrm{~d}=$ $-0.18)$.

We conducted two analyses to determine whether stable individual differences in corporate entitativity tracked intuitions about corporate personhood. First, did ratings of entitativity (controlling for prime condition) predict anthropomorphism? They did not ( $\beta$ $=0.02, S E=0.04, t=0.43, p=0.67)$. We also used textual analysis. In their essays, some participants discussed the corporation as if it were a coherent entity (high entitativity), and some discussed the corporation as if it were simply a collection of individuals (low entitativity). When this measure of entitativity is included in a linear regression model as a categorical predictor, it provides no predictive value for subsequent ratings of anthropomorphism. See Online Supplemental Materials for details.

These null results on entitativity suggest that our findings do not simply devolve to participants conceptualizing the corporation as a group of humans; indeed, belief in corporate personhood appears to be completely unrelated to assessments of entitativity.

In order to exclude the possibility that the difference in strength between morality and mind primes was due to superficial differences in the wording of these prompts, a modified experiment was run prompting participants to respond to whether corporations "have morals" (closing mirroring the other debate prompt, do corporations "have minds"). This experiment delivered indistinguishable results (see Study S2 of Online Supplemental Materials), suggesting that the smaller effect in the morality condition is probably not due to grammatical differences between the primes. This conclusion is lent further support by Study 5 . 
a

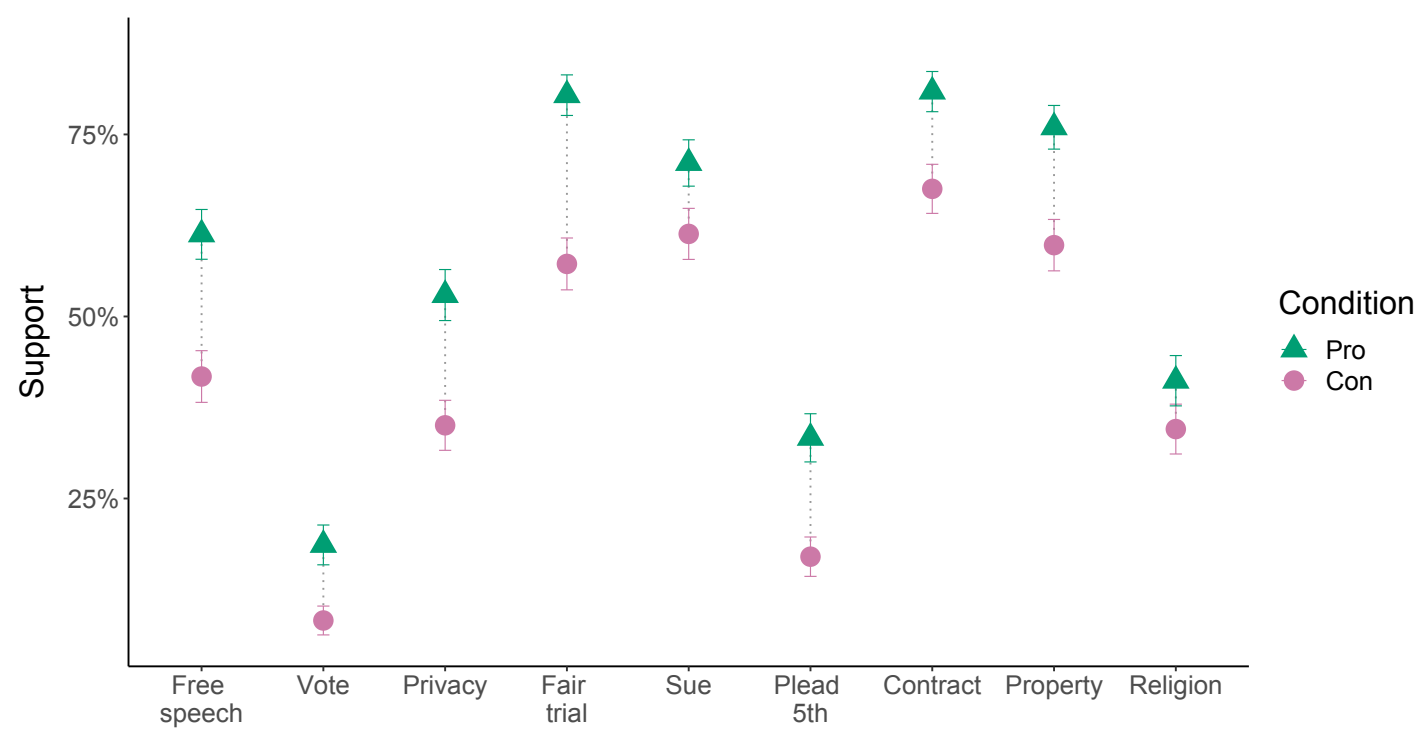

b

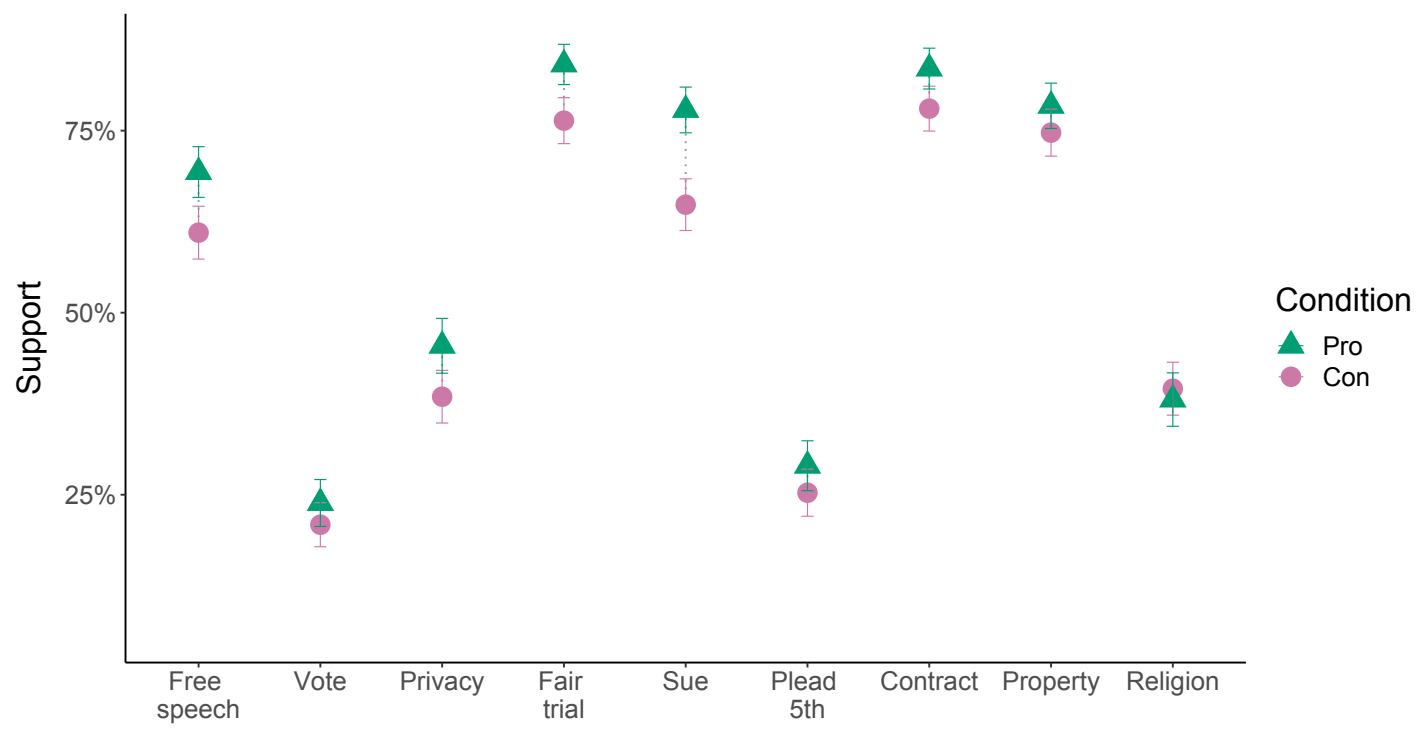

Figure 5. Support for corporate rights across four experimental conditions. Bars represent the standard error. $\mathbf{a}$, Mind prime $\mathbf{b}$, Morality prime. 


\section{Study 5}

The previous study showed a link between the salience of a corporation's anthropomorphic features and attributions of legal rights. This relationship may be unique to corporations. Alternatively, it may reflect a domain-general pattern in reasoning about personhood. If so, this would broaden the impact of this work: rather than reflecting a quirk of how humans think about corporate entities, it may reflect about how humans think of all sorts of edge cases with the potential for personhood. To test between these possibilities, we ran a modified version of the debate task, replacing a corporate entity with a biological one.

\section{Methods}

This study procedure was identical to Study 4, aside from the following.

Instead of asking about corporations, we asked about ants. The humble ant was selected for a few reasons. Per Study 1 , the ant $(M=28.5, M d n=20)$ has a comparable level of anthropomorphic personhood to the typical corporation $(M=31.0, M d n=17)$. The ant also has the convenient property where plausible arguments could be made on either side about it having a mind, or having a sense of morality. This makes it a desirable foil to the corporation from an experimental design standpoint. Finally, the ant is an entity whose legal personhood status is rarely discussed, thus providing an especially conservative test for whether anthropomorphic personhood is used to fuel convictions that an entity is deserving of human rights.

Because we were focusing on the ant, we presented a different set of rights to participants. We exchanged the nine potential corporate rights with nine rights that are often regarded as potentially applicable to animals (Singer, 1975). These were: the right to autonomy and self-determination, to be free from suffering, to be protected from extinction, to not be eaten, to not be forced to do work for humans, to not be tortured or abused, to not be used as property, to not be used as research subjects, and to not be used as human entertainment.

Because individual ants do not have ambiguous entitativity, this study did not include an entitativity question.

The morality debate prompt was "Ants have morals" rather than "Overall, ants act in a moral way". This allows for a tighter control with the mind debate prompt, "Ants have minds". See Study S2 for a demonstration that modifying this prompt does not alter results for judgments of corporations.

One advantage of this design is it constrains participants to think of a single target (ants) rather than what could be alternating targets across conditions (e.g. socially responsible company in one condition, profit-driven company in the other). Thus, jointly with Study 3 , these results strengthen the evidence for the relationship between mind/morality and attributions of legal personhood.

Participants were 886 Amazon Mechanical Turk workers who had not previously participated in the other versions of this study $\left(M d n_{\text {age }}=35,50 \%\right.$ female $)$. Those who did not follow the directions were excluded (12.9\%; same exclusion criteria as Study 3 ), leaving a total $\mathrm{N}$ of 772 . 


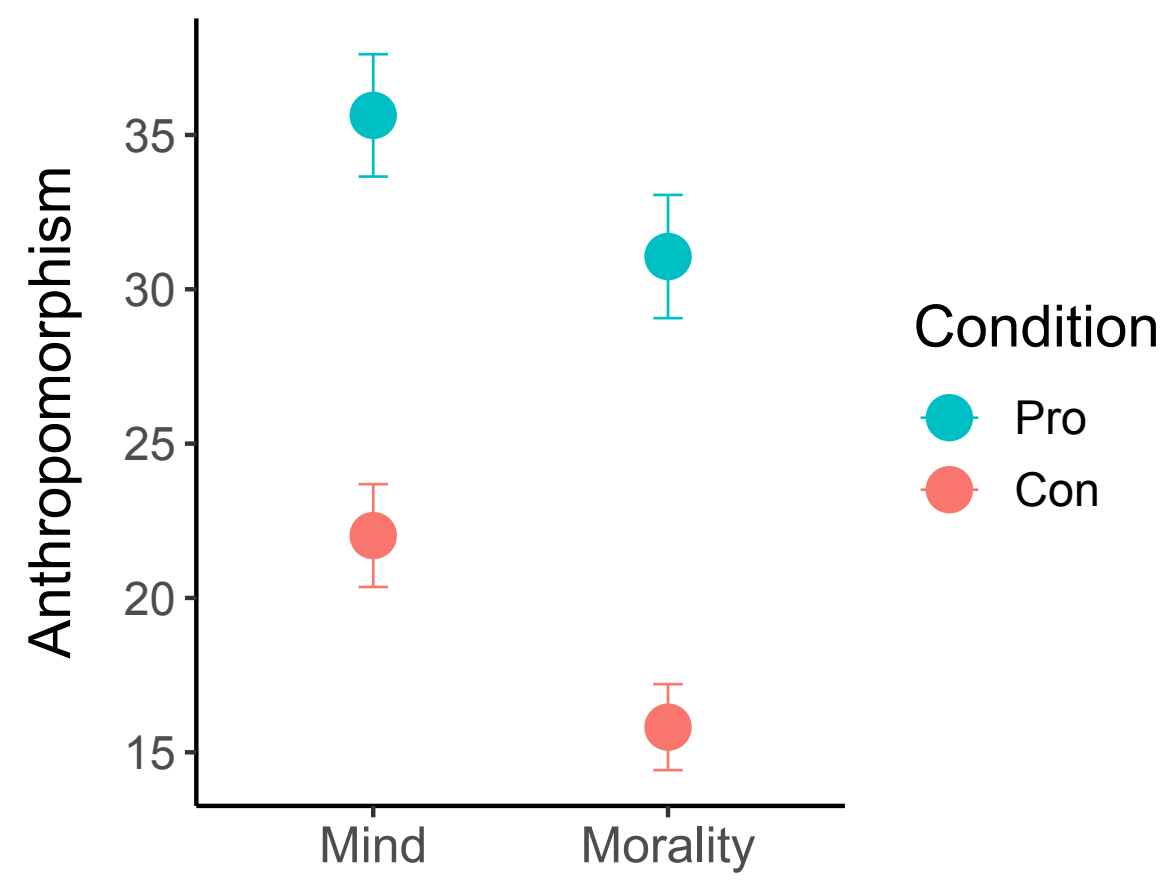

Figure 6. The effect of priming pro/con arguments that ants have minds, or morals, on personal beliefs that ants are like people. Bars represent the standard error.

\section{Results and discussion}

As with the previous study, responses to this debate task were quite varied. Below are some examples to give a sense of the types of responses participants wrote.

Pro mind "Ants move about in a coordinated way and respond to their surroundings. They pursue their objectives, finding food and bringing it back to the nest, and they can work around any obstacles that get in their way. A mind allows a living being to understand what is going on around them. Ants definitely have awareness of their environment as they go about life, so they do have minds."

Con mind "Ants do not have minds. They have very small brain cells that allow them to move and smell and follow things with their antennae, but they do not have minds that allow them to think or feel pleasure or fear. They are more like a machine that does what they were put in nature to do. I think if you have a mind you can think for yourself and have feeling, and since ants do not think for themselves or have feelings they do not have minds."

Pro morality "An ant's main goal in life is to protect the common good. Every ant in a colony has a purpose. They have a job. Whatever that job is it supports the common good. Whether it's collecting food or protecting the queen, every ant in the colony puts the common good before their own selfish ends. Some would say that 
is a highly moral life."10

Con morality "Ants do not have morals. They tend to come and go as they please with wanton disregard for anyone in their path. They encroach upon us and react negatively when approached. They can be quite the nuisance interrupting picnics ${ }^{11}$ biting people and in general just getting in the way, they behave this way because they have no morals."

We began with a series of manipulation check analyses. Participants who were assigned to defend the stance that ants have minds subsequently endorsed a personal belief that ants have minds to a greater degree $(M=69.5, S E=2.10)$ than those asked to defend the opposing stance $(M=29.7, S E=2.29$; pairwise t-test: $t(391)=12.8, p<0.001, d=1.29)$. Likewise, those asked to defend the view that ants have morals endorsed this as a personal belief more $(M=45.4, S E=2.61)$ than those asked to defend the opposing view $(M$ $=10.6, S E=1.45 ; t(281)=11.6, p<0.001, \mathrm{~d}=1.23)$. Those asked to defend the view that ants have morals also reported that ants are more morally good $(M=29.4, S E=2.84)$ than those defending the opposite view $(M=-4.10, S E=2.42 ; t(358)=8.96, p<0.001, \mathrm{~d}=0.93)$. These effects translated across debate task, such that those asked to defend the view that ants have morals were more liable to believe that ants have minds $(M=48.9, S E=2.45)$ than those arguing against $(M=31.4, S E=2.16 ; \mathrm{t}(362)=5.35, p<0.001, \mathrm{~d}=0.56)$. Defending the view that ants have minds had a reliable impact on personal belief that ants don't have morals $(M=23.6, S E=1.88)$ compared with defending the view that ants are mindless $(M$ $=18.0, S E=1.88 ; t(396)=2.11, p=0.04, \mathrm{~d}=0.21)$.

Next, we tested whether the debate task impacted endorsement of the ant's anthropomorphic personhood. Participants in the pro mind condition believed that ants have more personhood $(M=35.6, S E=1.98)$ than those in the con condition $(M=22.0, S E=1.67$; linear regression: standardized $\beta=0.25, t=5.22, p<0.001)$, and those in the pro morality condition believed that ants have more personhood $(M=31.1, S E=2.00)$ than those in the con condition $(M=15.8, S E=1.39$; standardized $\beta=0.31, t=6.34, p<0.001)$. Activating the belief that ants have minds, or morality, makes it seem more like a person (Figure 6).

In contrast to Study 4 (and S2), the morality prime's effect strength was just as strong as the mind prime's. The interaction effect was null for both anthropomorphization (standardized $\beta=0.06, t=0.46, p=0.65$ ) and rights granted (standardized $\beta=0.01, t=0.06$, $p=0.95$ ). This may be because participants have fewer preconceived notions about the morality of ants than the morality of corporations, leading to more flexible priming effects.

Naturally, we also wanted to know whether these manipulations impacted willingness to attribute legal personhood to ants. Those in the pro mind condition believed that ants should be granted more rights $(M=3.36, S E=0.20)$ than those in the con condition $(M=2.67, S E=0.19$; total effect: $\beta=0.69, S E=0.27, t=2.52, p=.01)$. As with corporations, the perceived personhood of ants mediated this effect. Nonparametric bootstrap analysis using 1000 Monte Carlo simulations reveals that the indirect effect through perceived personhood $(\beta=0.36, p<0.001,95 \% \mathrm{CI}=[0.18,0.57])$ explains $52 \%$ of the total effect from

\footnotetext{
${ }^{10}$ One of our participants even quoted the Bible: “Go to the ant, you sluggard! Consider her ways and be wise."

${ }^{11}$ A surprising number of participants claimed that the moral turpitude of ants was observable in their propensity to ruin picnics.
} 
a

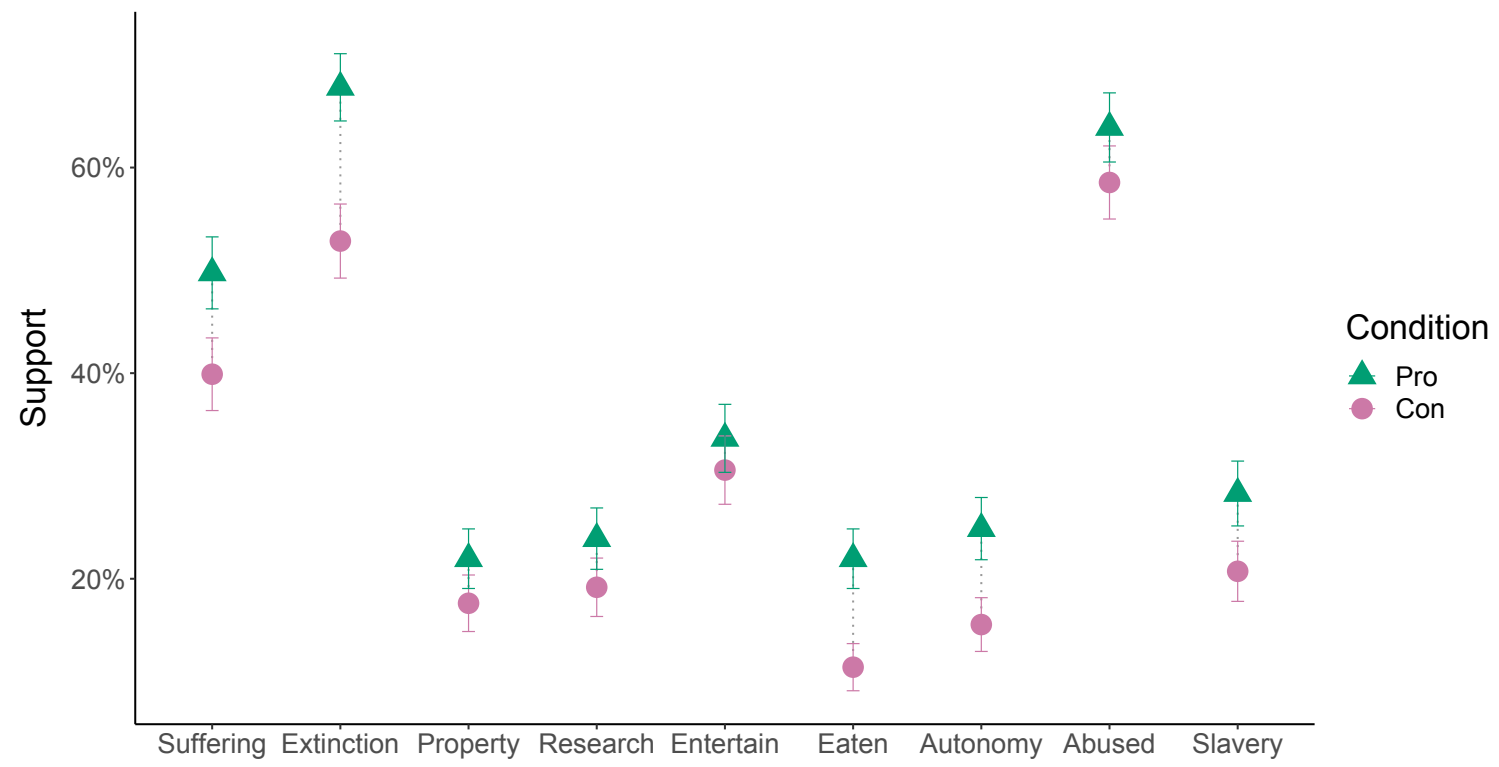

b

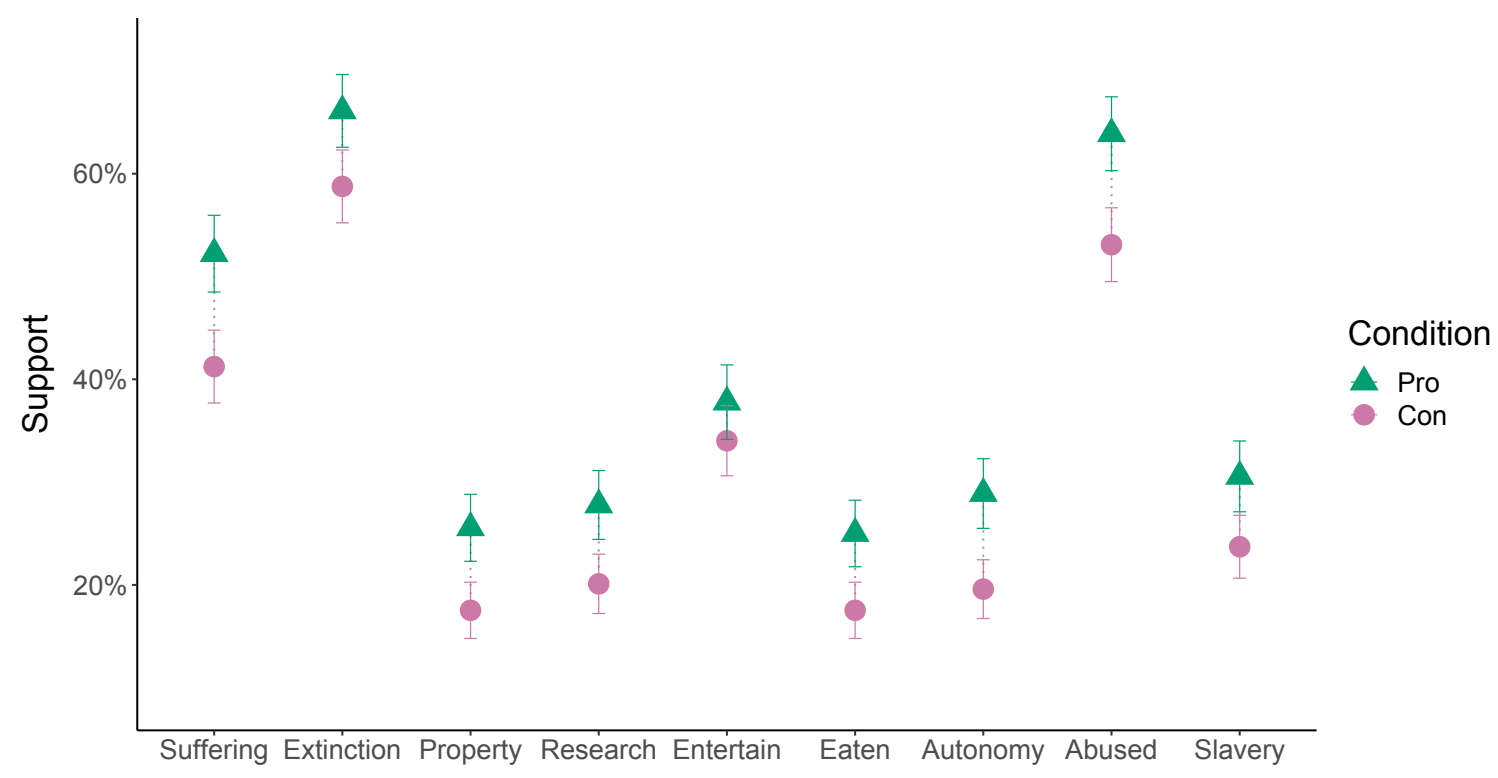

Figure 7. Support for animal rights for ants across four experimental conditions. Bars represent the standard error. $\mathbf{a}$, Mind prime $\mathbf{b}$, Morality prime.

the mind condition to beliefs about animal rights (direct effect: $\beta=0.33, p=0.23,95 \% \mathrm{CI}=$ $[-0.19,0.84])$.

Those in the pro morality condition also believed that ants should be granted more 
rights $(M=3.58, S E=0.21)$ than those in the con condition $(M=2.87, S E=0.19$; total effect: $\beta=0.72, S E=0.28, t=2.52, p=0.01$ ). When perceived personhood is included as a mediator, the effect from morality prime to rights attributions drops from significant (indirect effect: $\beta=0.39, p<0.001,95 \% \mathrm{CI}=[0.19,0.65]$ ) to nonsignificant (direct effect: $\beta=0.32, p=0.26,95 \% \mathrm{CI}=[-0.24,0.86])$. This explains $55 \%$ of the total effect from the morality condition to beliefs about animal rights, again suggesting that anthropomorphic personhood is an underlying force driving the judgments of legal personhood. The primes were similarly effective in changing support across different legal rights (Figure 7).

Participants in the "pro" debate conditions also believed ants should be held more responsible for their actions. Responsibility judgments were higher in the pro mind condition $(M=36.1, S E=2.35)$ than in the con condition $(M=22.9, S E=2.17$; standardized $\beta$ $=0.20, t=4.12, p<0.001)$. Responsibility judgments were higher in the pro morality condition $(M=38.1, S E=2.59)$ than in the con condition $(M=19.6, S E=2.21$; standardized $\beta=$ $0.27, t=5.46, p<0.001)$.

\section{General Discussion}

In spite of the current legal status of corporations as persons, it appears that ordinary people consider corporations to possess personhood in only a limited sense. A comment from one frustrated participant summarizes these results well: "I don't get it... How many times am I supposed to tell you that CORPORATIONS ARE NOT PEOPLE?" (emphasis and ellipses theirs).

We do appreciate that in some sense our conclusions are Kafkaesque: "Microsoft Corporation woke up one morning to discover it was a bug." Nonetheless, there is a deeper sense in which corporations are treated like people. Human traits are spontaneously attributed to the corporation, albeit to a lesser degree than for many animals. When a corporation displays more of these human qualities, it is granted more personhood. Furthermore, when assessing the rights and responsibilities due to the corporation, we use anthropomorphic criteria (possessing a mind and morality) to determine this eligibility.

We see some of these principles in action in a natural experiment (Study 2). A pharmaceutical company, Pfizer, experienced a boost in anthropomorphism relative to other companies in the period following the announcement of an effective COVID-19 vaccine. This pattern emerged both for Pfizer in comparison with other corporations as a whole, and for another pharmaceutical company (Johnson \& Johnson) whose vaccine was less well known at the time. While it seems that judgments of corporate personhood are updated according to new information, it is not clear how flexible or lasting such impressions are.

Given that the debate task alters support for matters of civic concern, it might seem natural to wonder whether this task modulates judgments across a timescale longer than a few minutes. We suspect that this effect, like all priming effects, is short-lived (Higgins, Bargh, \& Lombardi, 1985; Wyer \& Srull, 1989; Bargh, Gollwitzer, Lee-Chai, Barndollar, \& Trötschel, 2001). As a research tool, its primary use is to determine causal relationships, not serve as a public policy intervention. This is just as well, since its method of changing hearts and minds-by building intuitions off of misleading rhetoric - has more potential 
for abuse than justice. However, this research does suggest that changing the actual features of an entity (e.g. by making a corporation truly good; or, a scientific discovery that an animal species can feel pain) could have a lasting impact on whether people believe that entity is deserving of rights. The power of these simple changes is suggested by the wide range of personhood ratings naturally ascribed to different organizations (Study 1) and the personhood boost observed in a corporation that participates in a conspicuous act of moral good (Study 2).

At the start of the paper we wondered whether "corporate personhood" might be interchangeable, in the folk imagination, with "group of humans". Had this been the case, we should have found that corporations are granted a high degree of personhood. But Study 1 yielded just the opposite-corporations are so bereft of humanity that they are considered more similar to invertebrates than humans. In a sense, the corporation is less than the sum of its parts. Furthermore, if the corporation were made personlike only to the extent that it is perceived as the set of humans that comprise it, then low corporate entitativity ought to be associated with high corporate personhood. Yet we repeatedly fail to uncover any correspondence between entitativity and anthropomorphic personhood. Indeed, people who think of the corporation as equivalent to the individuals forming it are no more likely to anthropomorphize it. This means that, not only is the hypothesis incorrect, so is the fundamental assumption underlying it (that low entitativity in a human collective will lead that collective to seem more like a person). Instead, the corporate personhood observed in these studies is best characterized as actual-if modest-anthropomorphism. ${ }^{12}$

The present studies join the growing chorus of research that anthropomorphism increases moral care for nonhumans, from dogs to autonomous vehicles (Waytz, Cacioppo, \& Epley, 2010; Butterfield, Hill, \& Lord, 2012; Waytz, Heafner, \& Epley, 2014). This basic insight can now be generalized to include moral care for corporations, in the form of legal rights. Because anthropomorphism increases trust (Waytz, Cacioppo, \& Epley, 2010; Waytz et al., 2014), it is possible that anthropomorphized corporations are deemed more worthy of rights precisely because they are more trusted.

Anthropomorphism is generally depicted as a process whereby human attributes, especially mental attributes, are bestowed upon nonhumans (e.g. Waytz, Cacioppo, \& Epley, 2010). Our discovery that moral goodness increases anthropomorphism complicates this picture. Human beings are, of course, morally flawed creatures. So anthropomorphism must not be based straightforwardly on veridicality. Perhaps, instead, it is based on some idealized prototype of the "person. ${ }^{\prime 13}$ In this sense, the folk concept of personhood resembles the folk concept of the true self, which is prototypically morally good (Newman, Knobe, \& Bloom, 2014; Strohminger et al., 2017).

We have focused on one consequence of corporate anthropomorphization: legal personhood. However, there are likely other downstream effects, which may not necessarily all be desirable. In Study 3, for instance, ascriptions of moral responsibility for corpora-

\footnotetext{
${ }^{12}$ This conclusion seems far more pedestrian once we remember that the capacity to perceive individuals out of collectives is not reserved for corporations. The corporation emerges from its members much as a human being emerges from her cells. Corporations may or may not be people; but people are most certainly corporations.

13"What a piece of work is man," writes Shakespeare. "How infinite in faculty... In action how like an angel, In apprehension how like a god... The paragon of animals." Sure. As a prototype of personhood, this is right on the mark. The reality may be better summarized by Alexander Pope: "To err is human."
} 
tions go up when an anthropomorphism prime is employed. This complements prior research showing that imbuing corporations with anthropomorphic features induces harsher judgment when the corporation misbehaves, and amplifies the urge to seek retribution in the wake of scandal (Rai \& Diermeier, 2015; Puzakova, Kwak, \& Rocereto, 2013; Tang \& Gray, 2018). Full-fledged personhood is a sword with many edges, as anyone who has experienced the freedoms and responsibilities of adulthood can attest.

The normative literature has long debated whether anthropomorphic criteria might be relevant to legal personhood for corporations (Berle Jr, 1931; Dodd, 1932; French, 1979; Donaldson, 1980; Pettit, 2011; Orts, 2013; Sepinwall, 2015). And, in the parallel universe of animal rights scholarship, ethicists have argued that animals are deserving of personhood precisely because they have such human traits as intelligence, the ability to feel pain, and empathy (Bentham, 1789/1996; Singer, 1975; Regan, 1983). Although these are not typically thought of as similar perspectives, the present research reveals an underlying correspondence between how people reason about the personhood status of corporations and animals. Regardless of whether these criteria ought to be brought to bear in matters of jurisprudence, ordinary people do use such criteria when formulating their own beliefs.

It is worth taking a moment to appreciate just how remarkable these findings are. Ants-an animal whose personal rights are seldom, if ever, discussed seriously-are afforded a boost in legal personhood when their mental and moral attributes are raised to salience. The similarity of these results to those on corporate personhood suggests that the basis for attributing personhood across disparate entity types is undergirded by highly overlapping cognitive processes. Whether judging the rights belonging to ants or corporations, people draw on the same well of qualifications: Does it have a mind? and, Does it have morality?

While this paper has unveiled a similarity between corporations and insects on a general measure of anthropomorphic personhood, no doubt differences between these two entities would be revealed if "personhood" were decomposed into its constituent dimensions. For instance, our data suggest that corporations generally score higher in thinking than feeling, whereas ants score about the same in each (see Table S1 in the Supplement; see also K. Gray \& Wegner, 2010; Weisman et al., 2017). It is not difficult to see how these distinctions could be consequential when it comes to how rights are granted. After all, the set of typical rights in play for corporations are largely non-overlapping with those for animals-this may be a direct reflection of folk beliefs about the respective mental capacities of these entities. And the path from agency to legal personhood could be even more tortured: if we perceive something to be a malevolent agent, this could serve as a reason to curtail its rights. Further research could look at how individual anthropomorphic features affect which legal rights we feel impelled to grant (or withhold).

The studies presented here reveal that perceiving moral and mental capacities in two very different kinds of entity leads to attributions of anthropomorphic and legal personhood. Whether this causal arrow is bidirectional is indeterminate from our present data. Belief that an entity is a person (or has a person's rights) could well influence endorsement that it must also have the full suite of moral and mental capacities. In our view this is not at all unlikely, not least because attributions in social cognition are so often bidirectional (Bem, 1972). It is this plausibility that underlies our decision to treat rights and responsibilities as a predictor of anthropomorphism in Study 1. Nonetheless, this awaits further 
testing — with an experimental design—-to establish definitively.

The corporation is an "edge case" of personhood: it evinces ambiguous signals of similarity to a person. Such edge cases may be in a unique position relative to non edgecases (e.g. adults, rocks) in terms of our flexibility to potentially see them as persons. Then again, maybe not. Marginalized social outgroups undergo a kind of reverse anthropomorphization whereby they are denied human traits ("dehumanization"; Waytz, Epley, \& Cacioppo, 2010). And, as we show in this paper, the personhood of insects-most certainly not an edge case-can be pushed around as well. There may well be boundary conditions on which kinds of entities we can countenance as persons, but what these are we cannot yet say.

The present investigation provides an empirically-grounded-dare we say democratic-foundation for considering the personhood status of the corporation. In the eyes of the people, the corporation will never be as much of a person as an adult human, an infant, or even a dog. But the corporation is not stuck inexorably in its station. The more it exhibits signs of thought, feeling, and moral sensibility, the more it comes alive as a creature endowed with certain inalienable rights. By that same token, a corporation that conducts itself unethically, or mindlessly, contributes to its own dehumanization.

\section{References}

Aaker, J. L. (1997). Dimensions of brand personality. Journal of Marketing Research, 34, 347-356.

Aaker, J. L., Vohs, K. D., \& Mogilner, C. (2010). Nonprofits are seen as warm and for-profits as competent: Firm stereotypes matter. Journal of Consumer Research, 37(2), 224-237.

Abelson, R. P., Dasgupta, N., Park, J., \& Banaji, M. R. (1998). Perceptions of the collective other. Personality and Social Psychology Review, 2(4), 243-250.

Bargh, J. A., Gollwitzer, P. M., Lee-Chai, A., Barndollar, K., \& Trötschel, R. (2001). The automated will: Nonconscious activation and pursuit of behavioral goals. Journal of Personality and Social Psychology, 81(6), 1014-1027.

Barrett, J. L., \& Keil, F. C. (1996). Conceptualizing a nonnatural entity: Anthropomorphism in god concepts. Cognitive Psychology, 31(3), 219-247.

Bem, D. J. (1972). Self-perception theory. In L. Berkowitz (Ed.), Advances in experimental social psychology (Vol. 6, pp. 1-62). New York, NY: Academic Press.

Bentham, J. (1789/1996). An introduction to the principles of morals and legislation (J. H. Burns \& H. L. A. Hart, Eds.). Oxford, UK: Oxford University Press.

Bering, J. (2002). Intuitive conceptions of dead agents' minds: The natural foundations of afterlife beliefs as phenomenological boundary. Journal of Cognition and Culture, 2(4), 263-308.

Berle Jr, A. A. (1931). Corporate powers as powers in trust. Harvard Law Review, 44(7), 1049-1074.

Bhattacharjee, A., Dana, J., \& Baron, J. (2017). Anti-profit beliefs: How people neglect the societal benefits of profit. Journal of Personality and Social Psychology, 113(5), 671-696.

Boyer, P. (2001). Religion explained. New York, NY: Basic Books.

Brown, D. R. (1953). Stimulus-similarity and the anchoring of subjective scales. The American Journal of Psychology, 66(2), 199-214.

Burwell v. Hobby Lobby Stores, Inc. (Vol. 134) (No. No. 13-354). (2014). Supreme Court. 
Butterfield, M. E., Hill, S. E., \& Lord, C. G. (2012). Mangy mutt or furry friend? Anthropomorphism promotes animal welfare. Journal of Experimental Social Psychology, 48(4), 957-960.

Campbell, D. T. (1958). Common fate, similarity, and other indices of the status of aggregates of persons as social entities. Behavioral Science, 3(1), 14-25.

Citizens United v. Federal Election Commission (Vol. 552) (No. No. 07-953). (2008). Supreme Court.

Cooley, E., Payne, B. K., Cipolli III, W., Cameron, C. D., Berger, A., \& Gray, K. (2017). The paradox of group mind: "People in a group" have more mind than "a group of people". Journal of Experimental Psychology: General, 146(5), 691-699.

Critcher, C. R., \& Dunning, D. (2014). Thinking about others versus another: Three reasons judgments about collectives and individuals differ. Social and Personality Psychology Compass, 8(12), 687-698.

Dewey, J. (1925). The historic background of corporate legal personality. Yale Law Journal, 35(6), 655.

Dodd, E. M. (1932). For whom are corporate managers trustees? Harvard Law Review, 45(7), 1145-1163.

Dombrowski, D. A. (1997). Babies and beasts: The argument from marginal cases. Urbana, IL: University of Illinois Press.

Donaldson, T. (1980). Moral agency and corporations. Philosophy in Context, 10, 54-70.

Epley, N., Waytz, A., \& Cacioppo, J. T. (2007). On seeing human: a three-factor theory of anthropomorphism. Psychological Review, 114(4), 864-886.

Festinger, L. (1962). Cognitive dissonance. Scientific American, 207(4), 93-106.

French, P. A. (1979). The corporation as a moral person. American Philosophical Quarterly, 16(3), 207-215.

Goodwin, G. P., Piazza, J., \& Rozin, P. (2014). Moral character predominates in person perception and evaluation. Journal of Personality and Social Psychology, 106(1), 148168.

Gordon, G. (2015). Culture in corporate law or: A Black corporation, a Christian corporation, and a Maōri corporation walk into a bar... Seattle University Law Review, 39, 353.

Gray, H. M., Gray, K., \& Wegner, D. M. (2007). Dimensions of mind perception. Science, 315(5812), 619-619.

Gray, K., \& Wegner, D. (2009). Moral typecasting: Divergent perceptions of moral agents and moral patients. Journal of Personality and Social Psychology, 96(3), 505.

Gray, K., \& Wegner, D. M. (2010). Blaming God for our pain: Human suffering and the divine mind. Personality and Social Psychology Review, 14(1), 7-16.

Haran, U. (2013). A person-organization discontinuity in contract perception: Why corporations can get away with breaking contracts but individuals cannot. Management Science, 59(12), 2837-2853.

Haslam, N., Holland, E., \& Karasawa, M. (2013). Essentialism and entitativity across cultures. In M. Yuki \& M. Brewer (Eds.), Culture and group processes (pp. 17-37). New York, NY: Oxford University Press.

Heider, F., \& Simmel, M. (1944). An experimental study of apparent behavior. The American Journal of Psychology, 57(2), 243-259. 
Higgins, E. T., Bargh, J. A., \& Lombardi, W. J. (1985). Nature of priming effects on categorization. Journal of experimental psychology: Learning, Memory, and Cognition, 11(1), 59-69.

Higgins, E. T., \& Rholes, W. S. (1978). "Saying is believing": Effects of message modification on memory and liking for the person described. Journal of Experimental Social Psychology, 14(4), 363-378.

Hsee, C. K., Loewenstein, G. F., Blount, S., \& Bazerman, M. H. (1999). Preference reversals between joint and separate evaluations of options: A review and theoretical analysis. Psychological Bulletin, 125(5), 576-590.

Huebner, B., Bruno, M., \& Sarkissian, H. (2010). What does the nation of China think about phenomenal states? Review of Philosophy and Psychology, 1(2), 225-243.

Hunt, W. A. (1941). Anchoring effects in judgment. The American Journal of Psychology, 54(3), 395-403.

Jago, A. S., Kreps, T. A., \& Laurin, K. (in press). Collectives in organizations appear less morally motivated than individuals. Journal of Experimental Psychology: General.

Jago, A. S., \& Laurin, K. (2017). Corporate personhood: Lay perceptions and ethical consequences. Journal of Experimental Psychology: Applied, 23(1), 100-113.

Jago, A. S., \& Pfeffer, J. (2019). Organizations appear more unethical than individuals. Journal of Business Ethics, 160(1), 71-87.

Jenkins, A. C., Dodell-Feder, D., Saxe, R., \& Knobe, J. (2014). The neural bases of directed and spontaneous mental state attributions to group agents. PLoS One, 9(8), e105341.

Kant, I. (1785/1989). Foundations of the metaphysics of morals (L. W. t. Beck, Ed.). Englewood Cliffs, New Jersey: Prentice-Hall.

Kantorowicz, E. (1957). The king's two bodies: A study in medieval political theology. Princeton, NJ: Princeton University Press.

Knobe, J., \& Prinz, J. (2008). Intuitions about consciousness: Experimental studies. Phenomenology and the Cognitive Sciences, 7(1), 67-83.

Malle, B. F. (2010). The social and moral cognition of group agents. Journal of Law and Policy, 19(1), 95-136.

Melnikoff, D. E., \& Strohminger, N. (2020). The automatic influence of advocacy on lawyers and novices. Nature Human Behaviour, 1-7.

Mentovich, A., Huq, A., \& Cerf, M. (2016). The psychology of corporate rights: Perception of corporate versus individual rights to religious liberty, privacy, and free speech. Law and Human Behavior, 40(2), 195-210.

Michael, J., \& Szigeti, A. (2019). "The Group Knobe Effect": Evidence that people intuitively attribute agency and responsibility to groups. Philosophical Explorations, 22(1), 44-61.

Newman, G., Knobe, J., \& Bloom, P. (2014). Value judgments and the true self. Personality and Social Psychology Bulletin, 40(2), 203-216.

Orts, E. W. (2013). Business persons: A legal theory of the firm. Oxford, UK: Oxford University Press.

Pettit, P. (2011). Groups with minds of their own. In A. Goldman \& D. Whitcomb (Eds.), Social epistemology: Essential readings (pp. 242-268). Oxford, UK: Oxford University Press.

Phelan, M., Arico, A., \& Nichols, S. (2013). Thinking things and feeling things: on an 
alleged discontinuity in folk metaphysics of mind. Phenomenology and the Cognitive Sciences, 12(4), 703-725.

Plitt, M., Savjani, R. R., \& Eagleman, D. M. (2015). Are corporations people too? The neural correlates of moral judgments about companies and individuals. Social Neuroscience, 10(2), 113-125.

Preacher, K. J., \& Hayes, A. F. (2008). Asymptotic and resampling strategies for assessing and comparing indirect effects in multiple mediator models. Behavior Research Methods, 40(3), 879-891.

Puzakova, M., Kwak, H., \& Rocereto, J. F. (2013). When humanizing brands goes wrong: the detrimental effect of brand anthropomorphization amid product wrongdoings. Journal of Marketing, 77(3), 81-100.

Rai, T. S., \& Diermeier, D. (2015). Corporations are cyborgs: Organizations elicit anger but not sympathy when they can think but cannot feel. Organizational Behavior and Human Decision Processes, 126, 18-26.

Regan, T. (1983). The case for animal rights. Berkeley, CA: University of California Press.

Rogers, S. (1941). The anchoring of absolute judgments. Archives of Psychology, 37(261), $1-42$.

Ruskola, T. (2013). What is a corporation; Liberal, Confucian, and Socialist theories of enterprise organization (and state, family, and personhood). Seattle University Law Review, 37(639), 639-666.

Salmond, J. W. (1902). Jurisprudence: Or the theory of the law. London, UK: Stevens and Haynes.

Santa Clara County v. Southern Pacific Railroad. (1886). Supreme Court.

Sepinwall, A. J. (2015). Denying corporate rights and punishing corporate wrongs. Business Ethics Quarterly, 25(4), 517-534.

Sherif, M., Taub, D., \& Hovland, C. I. (1958). Assimilation and contrast effects of anchoring stimuli on judgments. Journal of Experimental Psychology, 55(2), 150-155.

Singer, P. (1975). Animal liberation: A new ethics for our treatment of animals. New York, NY: Random House.

Slovic, P. (1967). The relative influence of probabilities and payoffs upon perceived risk of a gamble. Psychonomic Science, 9(4), 223-224.

Strohminger, N., Newman, G., \& Knobe, J. (2017). The true self: A psychological concept distinct from the self. Perspectives on Psychological Science, 12(4), 551-560.

Strohminger, N., \& Nichols, S. (2014). The essential moral self. Cognition, 131(1), 159-171.

Sytsma, J. M., \& Machery, E. (2009). How to study folk intuitions about phenomenal consciousness. Philosophical Psychology, 22(1), 21-35.

Tang, S., \& Gray, K. (2018). CEOs imbue organizations with feelings, increasing punishment satisfaction and apology effectiveness. Journal of Experimental Social Psychology, $79,115-125$.

Trustees of Dartmouth College v. Woodward (Vol. 17) (No. 4 L. Ed. 629). (1819). Supreme Court.

Tversky, A., \& Kahneman, D. (1974). Judgment under uncertainty: Heuristics and biases. Science, 185(4157), 1124-1131.

Warren, M. A. (1973). On the moral and legal status of abortion. The Monist, 57(1), 43-61.

Waytz, A., Cacioppo, J., \& Epley, N. (2010). Who sees human? The stability and importance 
of individual differences in anthropomorphism. Perspectives on Psychological Science, 5(3), 219-232.

Waytz, A., Epley, N., \& Cacioppo, J. T. (2010). Social cognition unbound: Insights into anthropomorphism and dehumanization. Current Directions in Psychological Science, 19(1), 58-62.

Waytz, A., Heafner, J., \& Epley, N. (2014). The mind in the machine: Anthropomorphism increases trust in an autonomous vehicle. Journal of Experimental Social Psychology, 52, 113-117.

Waytz, A., \& Young, L. (2012). The group-member mind trade-off: Attributing mind to groups versus group members. Psychological Science, 23(1), 77-85.

Weisman, K., Dweck, C. S., \& Markman, E. M. (2017). Rethinking people's conceptions of mental life. Proceedings of the National Academy of Sciences, 114(43), 11374-11379.

Wojciszke, B., Bazinska, R., \& Jaworski, M. (1998). On the dominance of moral categories in impression formation. Personality and Social Psychology Bulletin, 24(12), 1251-1263.

Wyer, R. S., \& Srull, T. K. (1989). Memory and cognition in its social context. Lawrence Erlbaum. 